\title{
ARTICLES
}

\section{DEVELOPING DEVELOPMENT THEORY: LAW AND DEVELOPMENT ORTHODOXIES AND THE NORTHEAST ASIAN EXPERIENCE}

\author{
JOHN K. M. OHNESORGE
}

TABLE OF CONTENTS

1. INTRODUCTION.

2. THE ORTHODOXIES OF LAW AND

DEVELOPMENT

2.1. Law and Development in the Era of Modernization .............233

2.2. Dependency and World Systems Theory: Modernization's Discontents ..............................................239

2.3. The Washington Consensus Rule of Law..............................243

2.3.1. The Economics of the Washington Consensus ....245

2.3.2. The New Law and Development of the Washington Consensus

* Assistant Professor of Law and Assistant Director, East Asian Legal Studies Center, University of Wisconsin Law School. S.J.D., Harvard Law School, 2002. J.D., University of Minnesota Law School, 1989. I would like to thank Bill Alford, Marc Galanter, Don Clarke, Bryant Garth, Terry Halliday, Chuck Irish, Neil Komesar, Chang Hee Lee, Yoshi Matsuura, Veronica Taylor, David Trubek, and Frank Upham for their comments and suggestions. I would like to thank participants in workshops at Tsinghua University in Beijing, Seoul National University, Korea University, Chuo University, Doshisha University, Hokkaido University, Cornell Law School's 2004 conference on Japanese law, and participants in the panel "Law's New Empire: New Legal Techniques of Development" at the 2004 Annual Meeting of the Law \& Society Association. Much of this paper was written as a visiting researcher at Nagoya University's Center for Asian Legal Exchange (CALE), and I particularly want to thank CALE for their support. 
2.4. The Legal Origins of Orthodoxy: Law and Finance, Legal Origins, and the Common Law-Civil Law Divide.....252 2.5. The "Comprehensive Development" Rule of Law .................255

3. TESTING THE ORTHODOXIES AGAINST NORTHEAST ASIA ........258 3.1. Modernization (and its Discontents) Meet Northeast Asia .258

3.2. Northeast Asia and the Neoliberal Rule of Law ...................270

3.3. Legal Origins and Northeast Asia's Development................276

3.4. Comprehensive Development and Northeast Asia ................278

4. BEYOND CRITIQUE: NEW APPROACH TO LAW AND DEVELOPMENT FROM THE NORTHEAST ASIAN PRACTICE .......283

4.1. The Limits of Critique.........................................................284

4.2. Northeast Asia's Legal "Failures" as the Basis for an Alternative Approach to Legal Development Assistance......290

4.2.1. Northeast Asian Legal Instrumentalism and the Compartmentalization of Law

4.2.2. Legal Education, Legal Professions, and the Social Role of the Formal Legal System.............. 292

4.2.3. Contract and Property Rights Enforcement........294

4.2.4. Intellectual Property Law ....................................295

4.2.5. Additional Examples ..........................................297

4.3. Putting Substance over Form in Legal Technical

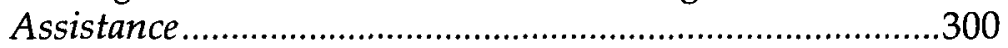

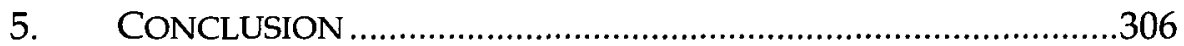

\section{INTRODUCTION}

Brazil has won five of the eighteen World Cup tournaments held since 1930, more than any other country. ${ }^{1}$ If soccer's world governing body, FIFA, wanted to create an approach to soccer development to help "backward" countries such as the United States become internationally competitive, would we expect FIFA to study Brazil's youth soccer system? Of course we would. We would accept that FIFA staff would bring to the project preconceived ideas and assumptions, and we would expect them to study successful countries other than Brazil, since not all of Brazil's practices are likely to be appropriate at all times, in all places. But we would expect FIFA to develop its approach based

1 Larry Rohter, In Brazil, Unpaved Path to Excellence, N.Y. TIMES, June 25, 2006, $\S 8$, at 1 ("How does Brazil do it? Year after year, World Cup after World Cup, soccer stars seem to roll out of here like cars off a factory assembly line."). 
on studies of successful national soccer programs, and given Brazil's success, we would certainly expect that it would take Brazil's experience seriously. At worst we would expect FIFA to check the proposals it developed against actual national experiences, and a program for soccer development that was largely contradicted by Brazil's historical experience would hardly be taken seriously.

Now, what if the world needed a theory addressing the role of law in economic development, but those responsible proceeded to develop that theory without paying serious attention to the role that law played in modern history's leading economic development success stories, for example, the "miracle" economies of Japan, South Korea and Taiwan ${ }^{2}$ in the latter half of the twentieth century? Strange as it sounds, this is exactly what has happened. As this Article will show, the law and development community ${ }^{3}$ has produced over recent decades a series of theories on law and development, none of which were derived from close study of Northeast Asia, and none of which fit very well with the existing evidence of how law actually did function in Northeast Asia during rapid economic development. Not surprisingly, there also has not been a history of trying to test the specific claims of these theories empirically against the Northeast Asian development success story.

Why does the world need a theory of law and development? Beyond our normal interest in understanding law's relation to social life, international financial institutions ("IFIs") such as the World Bank, the International Monetary Fund ("IMF"), and the Asian Development Bank devote enormous resources to programs advocating change in the legal systems of countries under their influence. Likewise, law and development initiatives play an important role in the work of major bilateral development assistance providers such as the United States Agency for

2 Hereinafter "Northeast Asia."

3 The law and development community consists largely of academics and development practitioners who focus on the socio-economic role of law in supporting development, variously defined. Academic participants have come largely from social science and law faculties in Europe and the United States, while practitioners have come from international financial institutions such as the World Bank, and from national development aid bureaucracies such as USAID. The idea of "law and development" as a field at the intersection of economic thought, legal thought, and development agency practices is expressed in THE New LaW AND ECONOMIC DeVElopmenT: A CRITICAL APPRAiSal (David M. Trubek \& Alvaro Santos eds., 2006). 
International Development ("USAID"), Germany's Gemeinschaft für technische Zusammenarbeit ("GTZ"), 5 and the Japan International Cooperation Agency ("JICA"). ${ }^{6}$ More importantly, these initiatives affect the lives of billions of people in developing countries, since even governments which maintain a high degree of sovereign autonomy, such as those of China and India, can be affected by the ideas, ideologies and policies that emanate from the World Bank or other law and development actors. And while the typical initiative targets the legal system of a poor country, or one that is transitioning from a planned to a market economy, it is important to remember that South Korea was the world's eleventh largest economy and a member of the OECD when, as a result of the Asian Financial Crisis and Korea's resulting need for international assistance, its legal system became the target of IMF, World Bank, and United States pressure.?

Today's histories of law and development typically begin during the modernization era of the 1950s and 1960s, though this fails to address the central role of law and legal imposition in the era of colonization. ${ }^{8}$ However, it is fair to date the current mode of

4 For a list of law and development projects at USAID see USAID Economic Growth \& Trade, http://www.usaid.gov/our_work/economic_growth_and _trade/eg/lir_where_active.htm (last visited Mar. 30, 2007); USAID Democracy \& Governance, http://www.usaid.gov/our_work/democracy_and_governance (last visited Mar. 30, 2007).

5 On the GTZ's law and development work in China, see GTZ Legal Advisory Service, http://www.gtz-legal-reform.org.cn/ (last visited Mar. 30, 2007).

6 Japan channels many of its law and development efforts through the International Cooperation Department ("ICD") of the Ministry of Justice's Research and Training Institute in Osaka. For more information, see The International Cooperation Department, http://web.moj.go.jp/ENGLISH/ MEOM/meom-01-05.html (last visited Mar. 30, 2007). For a discussion of Japan's current law and development initiatives, see generally Yoshiharu Matsuura, Toward A New Generation of Comparative Law: A Framework for Bilateral Collaboration in Law \& Development Projects in Asia, 23 WIS. INT'L L. J. 233 (2005); Veronica L. Taylor, New Markets, New Commodity: Japanese Legal Technical Assistance, 23 WIS. INT'L L.J. 251 (2005); Hikaru Oguchi, The Bureaucratic Sectionalism of Japan's Technical Cooperation in the Legal and Judicial Field: The Case of Legal Assistance in Laos (2004) (unpublished manuscript, on file with author).

7 See Hwa-Jin Kim, Living with the IMF: A New Approach to Corporate Governance and Regulation of Financial Institutions in Korea, 17 BERKELEY J. INT'L L. 61, 65 (1999) (describing the aftermath of Korea's financial turmoil in 1997). Korea is also engaged in law and development activities of its own through the Legal Research and Training Institute. See Legal Research \& Training Institute, http:// www.lrti.go.kr/ (last visited Mar. 30, 2007).

8 For example, lawyers played central roles in American colonial rule in the 
law and development activities to the 1960s, when primarily Western governments, institutions, and academics became involved with the legal systems of many developing and newlyindependent countries. ${ }^{9}$ Following decades of law and development activity, the world also came to recognize Northeast Asia's economic miracle and the region's outstanding economic performance became the subject of extensive analysis and debate by students of economic development from various disciplines. ${ }^{10}$ Surprisingly, however, given Northeast Asia's unquestioned economic success, the region's legal systems have been largely overlooked as potential sources of knowledge concerning the fundamental questions of law and development.11 Despite a rich Western language literature on Northeast Asian legal systems, ${ }^{12}$ and despite ventures by some scholars of Northeast Asian law into law and development debates, ${ }^{13}$ it is no overstatement to say that

Philippines, which has left a lasting legacy on Philippine law. See PAUL D. CARRINGTON, SPREADING AMERICA'S WORD: STORIES OF ITS LAWYER-MISSIONARIES (2005) (exploring over two centuries of efforts to replicate the laws and governments of foreign countries).

9 Though rarely mentioned now in Western discussions of law and development, the socialist world had its own version of law and development, supporting the spread of socialist legal institutions, for example from the Soviet Union to China in the 1950s. Both Western and socialist law and development initiatives were parallel aspects of the larger Cold War contest for global influence.

10 Economics, political science, and sociology are all well represented. The literature on Northeast Asian development is truly voluminous, and includes country-specific studies, as well as regionally-focused works.

11 An exception is THE ROLE OF LAW AND LEGAL INSTITUTIONS IN ASIAN ECONOMIC DEVELOPMENT, 1960-1995 (Katherina Pistor \& Philip A. Wellons, eds., 1999) (exploring competing theories about law and its relation to economic development).

12 There is of course an enormous amount of literature on Northeast Asian legal systems in Korean, Chinese, and Japanese language, but this is even less likely to appear in the law and development literature than works on Northeast Asia law in Western languages.

13 See, e.g., J. MARK RAMSEYer, OdD MARKETS IN JAPANESE HiSTORY (1996) (explaining how the Japanese legal system generally promoted mutually advantageous deals between private interests); LAW AND DEVELOPMENT IN EAST AND SOUTHEAST ASIA (Christoph Antons ed., 2003) (citing Japan and Singapore role models for Asian development and examining development related business laws in countries such as China, Korea, Indonesia, Malaysia, Vietnam, and the Philippines); LAW, CaPITALISM AND POWER IN ASIA: THE RULE OF LAW AND LEGAL INSTITUTIONS (Kanishka Jayasuriya ed., 1999) (suggesting that the notions of judicial organization and independence need to be located in the specific ideological and political context of East Asia); Donald C. Clarke, Economic Development and the Rights Hypothesis: The China Problem, 51 AM. J. COMP. L. 89 
scholarship on Northeast Asian law has played an insignificant role in the theoretical literature on law and development.

This lack of interest would not be a problem if Northeast Asia's economies were neither exceptionally good nor exceptionally bad. Thus, it could be argued that studying their legal systems would probably yield nothing very useful on the questions of law and development. Yet that, of course, is not the case. Northeast Asia's economies are the best examples we have of sustained and equitably distributed industrialization and development. Given their indisputable record of economic and social success, and given the fact that literature on Northeast Asian legal systems is widely available, the failure to place Northeast Asia at the core of law and development theorizing seems impossible to justify. This Article addresses that discrepancy in two ways. First, the dominant law and development orthodoxies will be examined through the lens of widely accepted understandings about the functioning of Northeast Asia's legal orders during the region's high growth decades.14 To the extent these orthodoxies cannot accommodate the Northeast Asian experience, it will be argued, they are deeply inadequate. In addition to this critical dimension, however, this

(2003) (discussing the relationship between property and contract rights and economic development in China); Tom Ginsburg, Does Law Matter for Economic Development? Evidence From East Asia, 34 LAW \& SOC'Y REV. 829 (2000) (reemphasizing the importance of legal institutions to economic growth); Frank K. Upham, Comment, Speculations on Legal Informality: On Winn's "Relational Practices and the Marginalization of Law," 28 LAW \& SOC'Y REV. 233 (1994) (discussing the World Bank's efforts to address "governance issues in borrowing countries"); Jane Kaufman Winn, Relational Practices and the Marginalization of Law: Informal Practices of Small Businesses in Taiwan, 28 LAW \& SOC'Y REV. 193 (1994) (discussing how the use of informal financing techniques by small businesses in Taiwan contributed to the development of Taiwan's economy); William P. Alford, The More Law, the More... ? Measuring Legal Reform in the People's Republic of China (Stanford Univ., Ctr. for Research on Econ. Dev. and Policy Reform, Working Paper No. 59, 2000) (examining the relationship between legal development and economic growth); Donald C. Clarke, Peter Murrell \& Susan Whiting, The Role of Law in China's Economic Development (George Washington Law Sch. Pub. Law \& Legal Theory Working Paper No. 187, 2006) (surveying China's legal system in the economic growth era); Frank Upham, Mythmaking in the Rule of Law Orthodoxy (Carnegie Endowment for Int'l Peace, Working Paper No. 30, 2002) (using the United States and post-World War Japan as examples of economies that have flourished under systems without formalist rules of law by developing a mix of formal and informal mechanisms to raise talent and capital).

14 Widely held understandings can be misleading or simply wrong, of course, especially with respect to foreign legal systems. Every effort will therefore be made to subject commonly held notions to appropriate scrutiny; however, this essay is not primarily a work of comparative law. 
Article will also articulate a positive vision of what the study of Northeast Asian law can contribute to law and development, offering a new approach to law and development activities informed by Northeast Asia's experience. It should not "take a theory to beat a theory." Strictly speaking, we should be willing to discard a theory once it has been disproved by evidence, and this should include our prevailing theories on law and economic development. On the other hand, the law and development efforts underway throughout the world are not going to stop even if their intellectual underpinnings are pulled away. The initiatives are going to continue, and the people actually doing the work are going to need some kind of coherent intellectual framework to guide their efforts. This bureaucratic imperative likely explains why these efforts often appear to repeat mistakes of the past, seemingly immune to a long tradition of insightful academic critique. As a matter of bureaucratic practice, if not of logic, it may therefore take at least a framework to beat a theory, and in that spirit, this Article offers a framework for understanding law and economic development that builds upon the Northeast Asian experience.

This proposed approach is novel because it incorporates explicitly the functioning of law and legal institutions during the Northeast Asian "miracle" era. More importantly, however, the approach offered here abandons the central assumption of all the orthodoxies it seeks to replace, which is that legal rules and institutions have clearly defined functions, and that the role of law and development efforts is to get client countries to adopt specific legal reforms that will reliably produce intended social outcomes. Instead of drawing on Northeast Asia to create yet another set of law and development prescriptions for implementation by developing countries, the Northeast Asian experience will be used here as evidence that the proper role of law and development assistance is both more modest and more demanding. More modest because it involves the admission of uncertainty and competing goals in the functioning of legal rules and institutions, yet more demanding in that it recognizes the top-down, formalist logic of existing orthodoxies is insufficient, and must be replaced by continued monitoring, learning-by-doing, and re-examination of both means and ends.

Insistence upon the importance of Northeast Asia for understanding law and development is premised, first of all, upon a methodological choice in favor of empirical analysis, not to the 
exclusion of other types of analysis, but as indispensable nonetheless. Even if one defines development in purely economic terms, law and legality make up only a small part of the broader social matrix that will be relevant to how any economy performs. This broader matrix includes non-legal factors such as education levels, demographics, natural resource endowments, geographical location, technology levels, domestic political institutions, social and cultural norms and practices, and international politics and economics. A country's policy choices with respect to these factors will often be reflected in positive law, of course, so social or economic reforms almost invariably involve legal change. Law and development activities aim for something more ambitious, however, and seek to put the functioning of legal systems at the center of the development equation. Because so many non-legal factors are clearly relevant to a country's economic performance, however, and because these factors, like legal system performance, tend to be difficult to isolate, quantify, and study scientifically, the best we can probably hope for in constructing law and development theory will help structure and guide inquiry, but will not constitute hard science.

The conviction behind this Article is that the best way to generate such "soft" theory is to do so inductively, studying recent examples of both economic success and economic failure, and then trying to draw defensible inferences based upon what can be observed about the functioning of law in these episodes. ${ }^{15}$ While studying failures can no doubt be instructive for understanding law and development, studying only a country that has a weak legal system and a weak economy, such as Russia in the early to mid-1990s, encourages the confusion of correlation with causation. In law and development studies this would mean blaming a lack of economic development on a weak legal system, when in fact causation might run the other way. Moreover, studying from the

15 For an application of this approach to the task of developing theory about economic development more generally, see ALICE H. AMSDEN, THE RISE OF "THE REST": CHALLENGES TO THE WEST FROM LATE-INDUSTRIALIZING ECONOMIES 290 (2001) ("Models that are inductive use concrete cases of industrial expansion rather than abstract hypotheses to explain growth and guide policy making."). Economist Dani Rodrik has applied a similar approach in his work on the role of government in East Asian development. Dani Rodrik, Getting Interventions Right: How South Korea and Taiwan Grew Rich (Nat'l Bureau of Econ. Res., Working Paper No. 4964, 1994). For an insightful example from the era of modernization theory, see Alexander Gerschenkron, The Modernization of Entrepreneurship, in MODERNIZATION: THE DYNAMICS OF GROWTH 246 (Myron Weiner ed., 1966). 
beginning those countries that developed most successfully (i.e., those in Northeast Asia), should help prevent a repeat of Max Weber's notorious England problem. Weber's "England problem" was the inconvenient fact that England, the birthplace of modern capitalism, had a legal system that did not really fit the formalrational ideal type that Weber thought was so important to modern capitalism. ${ }^{16}$ Today's law and development orthodoxies tend to replace Weber's Germanic bias with an Anglo-American bias, but run the risk of replicating his basic mistake if they do not deal explicitly with Northeast Asia. ${ }^{17}$ Moreover, even theories that are not developed inductively ought to be tested empirically, and given the vast scholarship on Northeast Asia's economic success, the region is well-suited to that task.

If this inductive, empirical approach is indeed an appropriate way to generate and test theory about law and development, there are several factors that make Northeast Asia an especially appropriate region to which it could be applied. First and foremost is "the miracle," the fact that Japan, then later South Korea and Taiwan, are the premier development success stories of the twentieth century. ${ }^{18}$ Japan's economy is now the world's

16 On Weber's "England Problem," see David M. Trubek, Max Weber on Law and the Rise of Capitalism, 1972 WIS. L. REV. 720 (analyzing the ways in which Weber attempted to overcome the "England Problem:" how capitalism emerged in England when it did not possess a formal legal system).

17 Some scholars are beginning to note that China is experiencing rapid economic growth without the kind of legal system that law and development orthodoxies posit as necessary, but much of what they are noticing now about China has been true for decades in China's neighbors. See generally Clarke et al., supra note 13 (examining the role of law in China's economic development).

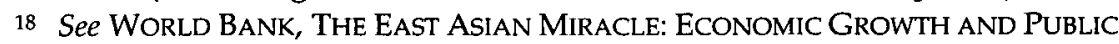
POLICY (1993) (discussing the rapid growth in East Asia and the relationship between the public and private sector). Japan's success came earliest, beginning in the decades around the turn of the 20th century, when Japan was transformed from a relatively isolated, largely agricultural economy into an industrial power capable of challenging Western military power in Asia, and of striking fear into Western manufacturers. After its industrial base was devastated in World War II, Japan experienced a second "miracle" during the 1950s, 1960s, and 1970s, as its economy quickly returned to its pre-War levels, then maintained growth rates that made Japan one of the world's richest societies by the 1980s. Taiwan and South Korea experienced the dark side of Japan's initial economic development, as they both were colonized by Japan and remained under Japanese rule until 1945. Although some see this period of Japanese colonial rule as not entirely negative with respect to post-independence economic development, the Korean and Taiwanese "miracles" are normally seen as beginning around 1960, and lasting until some time in the 1980s. An important strain of economics scholarship criticizes the "miracle" label on the ground that all, or nearly all, of 
second largest, behind only the United States, while Taiwan currently stands in seventh, and South Korea at eleventh. Beyond overall growth figures, there are several other factors that one can point to as evidence of a development miracle in Northeast Asia. With respect to technology, for example, within the space of a few decades Japan, and later Taiwan and South Korea, moved from technological backwardness to world frontiers in many fields. ${ }^{19}$ In the 1950s, South Korea was one of the world's poorest countries, considered a basket case by Western observers, ${ }^{20}$ but by the 1970 s its scientific and engineering expertise allowed it credibly to threaten an atomic weapons program. ${ }^{21}$ Today Korean scientists are at the forefront of stem cell research, ${ }^{22}$ while Korean manufacturers such as Samsung Electronics, Hyundai Motors, and Pohang Iron and Steel Corporation (POSCO) are internationally

Northeast Asia's economic growth can be explained using normal tools of economic analysis. See Alwyn Young, The Tyranny of Numbers: Confronting the Statistical Realities of the East Asian Growth Experience, 110 Q.J. ECON. 641 (1995); Paul Krugman, The Myth of Asia's Miracle, 73 FOREIGN AfFAIRS 62 (1994) (cautioning against the popular enthusiasm surrounding Asia's economic boom). While this may be true, it begs the comparative question of why Northeast Asian economies were able to do what so many others could not.

19 See Albert G. Z. Hu \& Adam B. Jaffe, Patent Citations and International Knowledge Flow: The Cases of Korea and Taiwan 1 (Nat'l Bureau of Econ. Research, Working Paper No. 8528, 2001) ("Korea and Taiwan are two of the newly industrializing economies that have achieved tremendous technological progress and economic growth. Both have graduated from imitation to innovation within a single generation, by building their indigenous technological capabilities and moving up the technology ladder.").

20 See William Easterly, Explaining Miracles: Growth Regressions Meet the Gang of Four 12 (World Bank, Policy Research Paper No. 1250, 1994) ("The first World Bank mission to Korea in the early 1960s described the development as ludicrously optimistic ....").

21 See Young-sun Ha, Nuclearization of Small States and World Order: The Case of Korea, 18 ASIAN SURV. 1134, 1138 (1978) (explaining that since South Korea was able to produce fissile materials in the 1970s, it also had the basic knowledge required for nuclear technology). By the 1970s Taiwan, too, had the technological capability to mount a nuclear weapons program. See DENNY RoY, TAIWAN: A POLITICAL HISTORY 143-44 (2003) (recounting the International Atomic Energy Agency's discovery of Taiwan's clandestine nuclear weapons program).

22 As of June 2005, South Korea had published 29 human embryonic stem cell lines, second only to the 46 published by the United States. Richard Gardner \& Tim Watson, $A$ Patchwork of Laws, in THE FUTURE OF STEM CELLS, FinANCIAL TIMES AND SCIENTIFIC AMERICAN SPECIAL REPORT, at A16, A21 (Lionel Barber \& John Rennie eds., 2005). 
preeminent in their fields. ${ }^{23}$ Taiwan's science and technology are also at world frontiers in many fields, particularly semiconductors and personal computers. ${ }^{24}$ Social indicators also show remarkable progress, as health care, life spans, education levels, and diet all showed remarkable improvement. ${ }^{25}$ One of the most striking aspects of these achievements is that they have been shared comparatively equally, so that Northeast Asian societies do not display the vast disparities between rich and poor that often accompany rapid economic expansions. ${ }^{26}$

In addition, although observers often focus on the similarities among Japan, South Korea and Taiwan, as successful "developmental states," 27 for example, there is also a great deal of diversity among the three countries in areas that likely matter for development. Post-War Japan has been a democracy, for example, while Taiwan and Korea were both authoritarian for large parts of their high-growth periods. Despite the fact that Taiwan and Korea were both colonies of Japan, as a result of differing colonial policies $^{28}$ and other historical factors, ${ }^{29}$ their post-WWII histories

23 See Tae-gyu Kim, 'Republic of Samsung' Builds up in Korea, KOREA TIMES, May 17, 2005; B. J. Lee, Rolling in the Dough, NEWSWEEK (INT'L EDITION), May 23, 2005 , at 40 .

24 See, e.g., Andrew Ross Sorkin \& Steve Lohr, I.B.M. Said to Put Its PC Business on the Market, N.Y. TIMES, Dec. 3, 2004, at A1 (reporting on I.B.M.'s decision to put up for sale its personal computing division).

25 See WORLD BANK, THE EAST ASIAN MIRACle, supra note 18, at fig. 3 (displaying graphically the dramatic improvements in human welfare in Asian countries from 1965 to 1990 ).

26 See id. at 49 ("Economic growth is like a handicapped race; the returns to equal effort at accumulation are greater for the poor economy. If the rates of accumulation of all economies, rich and poor, are roughly similar, neoclassical growth models predict that poor economies will eventually catch up to the leaders.").

27 See, e.g., Robert WADE, GOVERnING THE MARKET: ECONOMIC THEORY AND THE ROLE OF GOVERNMENT IN EAST ASIAN INDUSTRIALIZATION (1990) (attributing the success of developing East Asian countries to the synergy between free markets and government administration).

28 Japan's political policies towards Korea were harsher and more ambitious than those towards Taiwan, at times calling for Korea to be incorporated into Japan proper, and for Korean culture to be essentially eradicated. Taiwan, by contrast, was treated much more like a "normal" colony. Japan's economic policies towards the two colonies differed as well, with Taiwan remaining a largely unindustrialized exporter of agricultural products to Japan, while Korea, particularly the northern regions, became fairly heavy industrialized.

29 Taiwan ended up being ruled by the Nationalist government that had substantial experience in China prior to fleeing to Taiwan in the late 1940s, as it was losing the Chinese civil war to Mao Zedong and the communists. Korea, in 
have differed substantially. Important differences can be seen with respect to foreign investment ${ }^{30}$ and state ownership of industry, ${ }^{31}$ and in patterns of private ownership of industry ${ }^{32}$ and defense expenditures. ${ }^{33}$ While recognizing that overemphasizing similarities among Asian societies can be evidence of some unfortunate "isms," 34 the pattern of broad similarities with relatively discrete differences which Northeast Asia offers should facilitate empirically-based theorizing that will be more convincing than what could be done with a sample of countries which had little in common. ${ }^{35}$

contrast, was under United States military rule until 1948, after which formal authority was turned over to a newly established political system dominated by United States protégée Syngman Rhee, who won the first presidential election.

30 Policies toward foreign investment have varied among the three countries, as have levels. Historically, foreign direct investment played a greater role in Taiwan than in Korea or Japan, however the Asian Financial Crisis and Japan's sustained economic slump have lead to changes in those economies that have resulted in higher levels of foreign investment. Comparative statistics on foreign direct investment (FDI) are available on the Country Fact Sheets website of the United Nations Conference on Trade and Development (UNCTAD), http://www.unctad.org/Templates/Page.asp?intItemID=2441\&lang=1 (last visited Apr. 8, 2007).

31 Japan's economy was characterized by little direct state ownership, while the level in Korea was higher, and the level in Taiwan was higher yet. For a discussion of the differences between Taiwan and Korea, see Alice H. Amsden, Big Business and Urban Congestion in Taiwan: The Origins of Small Enterprise and Regionally Decentralized Industry (Respectively), 19 WORLD DEv. 1121 (1991). Note that some see the attempt to define public and private realms in the developmental state as an attempt to impose a construct that is not fully applicable. See generally Lee, supra note 23 (concerning government control over finance in South Korea).

32 Most of the large private firms in Korea and Taiwan have been family controlled, while this has not been the case in Japan. Stijn Claessens et al., Who Controls East Asian Corporations? 30 (World Bank Policy Research Working Paper 2054, 1999). three.

33 Not surprisingly, Korea has the highest per capita defense spending of the

34 These include orientalism, essentialism, and racism, to name a few.

35 Several scholars have examined specific differences in Northeast Asia against their relatively common background conditions. See RICHARD WHITLEY, BUSINESS SYSTEMS IN EAST ASIA (1992) (comparing business structures in Japan, Korea, Taiwan, and Hong Kong); Gary G. Hamilton \& Nicole Woolsey Biggart, Market, Culture, and Authority: A Comparative Analysis of Management and Organization in the Far East, 94 AM. J. Soc. S52 (Supp. 1988) (examining different outcomes with respect to enterprise organization, despite relatively similar background conditions); John K.M. Ohnesorge, States, Industrial Policies $\mathcal{E}$ Antidumping Enforcement in Japan, South Korea and Taiwan, 3 BUFF. J. INT'L. L. 289 (1997) (comparing antidumping practices in Japan, Korea and Taiwan); Hun Joo 
This Article seeks to construct such theory by demonstrating the following: the success of Northeast Asia, in spite of its failure to conform to law and development theories from the 1960s to the present, requires an in-depth reassessment of the framework used by IFIs, scholars, and policy makers to formulate law and development policy. Section 2 chronicles the key orthodoxies that have informed law and development efforts from the 1960s to today, and Section 3 then demonstrates that in important ways none of them can be reconciled with the Northeast Asian law and development experience. This lays the groundwork for Section 4, which draws upon the Northeast Asian experience, but does so in order to inform a new approach to law and development, not as the basis for yet another orthodoxy to be imposed upon developing countries.

\section{THE ORTHODOXIES OF LAW AND DEVELOPMENT}

Looking at the history of law and development thinking, particularly in the United States, one can identify two quite distinct dominant orthodoxies ${ }^{36}$ which prevailed in the 1960 s and the 1990s, respectively. To those two orthodoxies must now be added two current "proto-orthodoxies," which at the present time can be seen as contending for dominance. ${ }^{37}$ This Section chronicles the development of these orthodoxies and proto-orthodoxies.

Discussions of law and development orthodoxies typically begin with what Trubek and Galanter dubbed "liberal legality," the approach associated with modernization theory of the 1950s

Park, Small Business in Korea, Japan, and Taiwan: Dirigiste Coalition Politics and Financial Policies Compared, 41 AsIAN SURV. 846 (2001) (comparing different policies towards small and medium enterprises).

36 Although it might be useful to think of these orthodoxies as paradigms in the Kuhnian sense, use of that term seems to demand a type of internal, psychological analysis that will not be attempted here. I am not privy to whether people and institutions who advocate particular law and development orthodoxies do so as a result of operating within a Kuhnian paradigm which constrains and structures the ways that they conceive the issues and the universe of possible responses, but for purposes of this exercise it may not matter. Furthermore, unlike the natural sciences, for which Kuhn developed his ideas, law and development initiatives are so rarely connected with a research agenda, as opposed to an active, political agenda, that it seems better to analyze these activities in more traditional political action terms.

37 Similar periodizations are employed by contributors to TRUBEK \& SANTOS, supra note 3 . 
and 1960s. ${ }^{38}$ That orthodoxy was largely spent by the early 1970s, as the broader modernization ethos succumbed to realities such as the Vietnam War and the extent to which "modern" Western societies did not themselves fit the model, and as funding for law and development activities dried up. ${ }^{39}$ The critics of modernization theory did not succeed in providing an alternative law and development orthodoxy, but they did produce two influential bodies of work-dependency theory and the world systems approach - which will also be discussed here. The second commonly recognized era of law and development began around 1989 , with the fall of the Berlin Wall and the subsequent collapse of the Soviet Union. Much had changed in the economics academy since the 1970s, and the new law and development orthodoxy that developed was a neoliberal rule of law orthodoxy associated with what has been termed the "Washington Consensus." 40 While this intellectual history is generally accepted, this Article argues that a complete picture must now include two more recent protoorthodoxies, which are quite distinctive, and which might be seen as contending for dominance. One of these, termed here the "comprehensive development rule of law," can be associated with trends within the World Bank under President James Wolfensohn, ${ }^{41}$ while the other, termed here the "legal origins"

38 See David M. Trubek \& Marc Galanter, Scholars in Self-Estrangement: Some Reflections on the Crisis in Law and Development Studies in the United States, 1974 Wis. L. REV. 1062, 1070 ("In the early years of the law and development movement many scholars and assistance officials shared a tacit set of assumptions about the relationship between law and development.... [T] he basic presuppositions of this paradigm ... we shall call 'liberal legalism ... . '" $)$. A useful recent introduction to modernization theory is NILS GILMAN, MANDARINS OF THE FUTURE: MODERNIZATION THEORY IN COLD WAR AMERICA (2003).

39 See GILMAN, supra note 38.

40 John K.M. Ohnesorge, The Rule of Law, Economic Development, and the Developmental States of Northeast Asia, in LAW AND DEVELOPMENT IN EAST AND SOUTHEAST ASIA 91 (Christoph Antons ed., 2003) (examining the application of rule of law rhetoric in the study of Northeast Asian economies). On the origins of the "Washington consensus" concept, see John Williamson, From Reform Agenda to Damaged Brand Name: A Short History of the Washington Consensus and Suggestions for What to Do Next, FIN. \& DEV., Sept. 2003, at 10.

41 See Kerry Rittich, The Future of Law and Development: Second-Generation Reforms and the Incorporation of the Social, in Trubek \& Santos, supra note 3, at 203 (discussing various World Bank trends and related reform); see also John K.M. Ohnesorge, On Rule of Law Rhetoric, Economic Development, and Northeast Asia 7 (Univ. of Wis. Law Sch. Legal Studies Research Paper Series, Paper No. 1026, 2006), available at http://ssrn.com/abstract=918122 (describing President Wolfenson's proposed legal reforms in 1999). 
approach, has its origins in the writings of financial economists originally interested in legal systems and financial system performance.42 As will be developed in Section 3, below, this Article is inspired by the conviction that none of these orthodoxies fares well when examined in light of the Northeast Asian experience of law and economic development.

\subsection{Law and Development in the Era of Modernization}

The modernization orthodoxy saw its heyday in the 1950s and 1960 s, but as will be seen, some of its core assumptions remain influential. Certainly the best chronicled orthodoxy in law and development, the modernization orthodoxy was not concerned only with economic development, but saw development as a process by which "traditional" or "backwards" societies would transform along a host of dimensions to become "modern." Scholars from a range of disciplines shared the modernization ethos-indeed interdisciplinarity was fundamental to the goal of developing a total theory of society ${ }^{43}$ - so they naturally produced traditional-modern schemas based upon their disciplinary concerns. The following schema, produced by Harvard social psychologist Alex Inkeles, nicely captures the ethos as it lays out the factors said to characterize "modern man":

(1) openness to new experience, both with people and with new ways of doing things such as attempting to control births;

(2) the assertion of increasing independence from the authority of traditional figures like parents and priests and a shift of allegiance to leaders of government, public affairs, trade unions, cooperatives, and the like;

(3) belief in the efficacy of science and medicine,

42 See John K.M. Ohnesorge, China's Economic Transition and the New Legal Origins Literature, 14 CHINA ECON. REv. 485 (2003) (discussing the literature of the "legal origins" approach). This literature is also referred to as the "law and finance" literature, and sometimes as the "law matters" literature.

43 See GILMAN, supra note 38, at 77-79 (discussing interdisciplinary aspects of modernization initiatives at Harvard, Yale, and Chicago, and tracing interdisciplinary focus to Talcott Parson's search for a unified theory of social action in which the role of neoclassical economics would be limited). 
and a general abandonment of passivity and fatalism in the face of life's difficulties; and

(4) ambition for oneself and one's children to achieve high occupational and educational goals.

Men who manifest these characteristics:

(5) like people to be on time and show an interest in carefully planning their affairs in advance; ...

(6) show strong interest and take an active part in civic and community affairs and local politics; and

(7) strive energetically to keep up with the news, and within this effort to prefer news of national and international import over items dealing with sports, religion, or purely local affairs. ${ }^{44}$

This type of schema was central to modernization research, sometimes, as here, leaving the "traditional" side of the equation unspecified, but often including both. ${ }^{45}$ Modernization scholars clearly believed that it was possible to identify objectively valid characteristics of "modernity" in constructs like this, but in retrospect modern man looks less like a scientifically useful general type than like the self-image of a liberal Harvard professor. One suspects that if modern man had ventured from Harvard Square into Somerville or East Cambridge he might have realized that he did not need to fly to India to collect data on "traditional man," who likes reading the sports section, listens to his priest (at least some of the time), and is not always punctual or involved in local politics. Falling into the same unfortunate dynamic, "modern society" came to resemble nothing so much as liberal intellectual America's vision of itself, a social welfare state characterized by a

44 Alex Inkeles, Making Men Modern: On the Causes and Consequences of Individual Change in Six Developing Countries, 75 AM. J. SoC. 208, 210 (1969).

45 Perhaps the most influential of these schemas, Talcott Parsons's "pattern variables" included both sides in the variables, said to capture the dynamics of all societies. For another effort by Parsons along the same lines, see Talcott Parsons, Evolutionary Universals in Society, 29 AM. SOC. REV. 339 (1964). 
homogeneous, secular political culture, pluralist democratic politics, industrialization, urbanization, occupational specialization, high social mobility, and the nuclear family, among other aspects. 46

The specifically legal dimension of the modernization ethos shared important elements of the general approach. Law reform was not simply about economic development, it was about helping Third World countries develop "modern" legal systems. ${ }^{47}$ A modern legal system, like a modern society for modernization theorists more generally, was supposed to be the ultimate stage in a more or less universal process of societal evolution, but at the same time bore a striking resemblance to an idealized vision of the contemporary United States legal system. ${ }^{48}$ And again, like modernization theory more generally, the idealized picture reflected the normative commitments of America's moderate, liberal elite, who at that time could claim to represent an ideological consensus in a way that seems fantastic now..$^{49}$ In addition, the elements of "liberal legality" were distinct yet mutually reinforcing, so that one could have faith that assisting in the modernization of one institution or body of law would have salutary "spillover effects" on the whole system. 50 For example, one might believe in the priority of economic growth over other aspects of development, as some modernization scholars did, but

46 See GILMAN, supra note 38 (analyzing theories advanced by scholars who focused on various attributes of the modernization theory).

47 See Trubek \& Galanter, supra note 38, at 1073-74 (discussing the goal of modernizing legal systems as a means of fostering social development).

48 See id. at 1079-80 (discussing the assumption that "any activity that was designed to change legal institutions of Third World countries to make them more like those of the United States would be an effective and morally worthy pursuit.").

49 Even if real at the time, that consensus papered over disagreements that had existed before, and have since resurfaced to dominate American politics. For example, the American political right's current project of enlisting fundamentalist Christians and Catholics, on religious grounds, against the federal judiciary represents the sort of ideological warfare that should have been long discarded in the legal culture of a "modern" society, though of course it would have been perfectly understandable to the left of the New Deal and prior generations. Likewise, the recent revival of the old battle against teaching evolution in the public schools, certainly best explained as a result of people's religious beliefs, suggests that the post-ideology "modernization" consensus was exceptional, rather than a final, higher stage of social evolution.

50 On "spill-over" arguments and the neoliberal rule of law, see Ohnesorge, supra note 41 , at 4 . 
even if one did not, one could still assist in economic law reform with confidence that the "seamless web" nature of the legal system would result in better performance on non-economic dimensions as well. ${ }^{51}$

What were the specific elements of this idealized "modern" legal system circa the 1960s? In terms of its overall function, law was to be the instrument by which reformist Third World governments would bring about social change in the direction of socially responsible capitalism and pluralist democracy. ${ }^{52}$ This view entailed both a faith that Third World states were committed to the public interest, and a faith that law could be made "potent" and predictable enough to serve this social engineering function..$^{53}$ Beyond the image of law itself, the actual emphasis of law and development efforts was very much on legal education. This included an assumption that increasing the number of lawyers in a society marked progress towards the rule of law, a debatable notion that still persists in the field. ${ }^{54}$ As David Trubek has argued recently, the modern, instrumental conception of law seemed to require an attack on four distinct manifestations of legal formalism: formalism in judicial reasoning, formalism in law making, formalism in the way legal professions understood the function of the lawyer, and importantly, formalism in the way law was taught. .5

In addition to programs to introduce specific statutory or institutional changes, therefore, reforming legal education became an important fulcrum for gaining leverage to reorient entire legal cultures, and one does not really have to read between the lines to see that the goal was Americanization.56 Americanizing legal

51 See Trubek \& Galanter, supra note 38, at 1075 (discussing the view "that a strengthened legal profession would foster development.").

52 Id. at 1063.

53 Id.

54 Email from Professor William P. Alford, Harvard Law School (Aug. 23, 2005) (on file with author).

55 David M. Trubek, The "Rule of Law" in Development Assistance: Past, Present, and Future, in TRUBEK \& SANTOS, supra note 3, at 74, 76 (describing the shortcomings of legal education in Latin America).

56 In the words of USAID General Counsel Thomas Farmer in 1966, "[T]he explanation [for the woeful performance of developing country lawyers] seems to lie first of all in the nature of their legal education - a system generally based on foreign models more responsive to conditions in Europe than to the distinctive needs of the developing societies." Thomas L. Farmer, General Counsel, Agency for Int'l Dev., U.S. Dep't of State, Address Before the Council of the Section of Int'l 
education would help cure Third World lawyers of their penchant for formalism, turning them from Weberian automatons into pragmatic problem solvers. Quoting USAID's General Counsel Thomas Farmer,

[E]ven more important [than flawed legal education] is the lawyer's preoccupation with formal rules rather than with creative problem-solving-whether the problems are those of a government trying to implement a new development program or those of private clients (local or foreign), trying to conduct business in a society experiencing the many stresses and strains besetting the developing countries. ${ }^{57}$

Freeing Third World lawyers from their formalist fetters would allow a crucial expansion of their social roles, both in government service and in private practice, and it is clear in hindsight how this role was based on the image of the elite American business lawyer, moving easily between government service and high-level corporate practice:

The role of the lawyer in most developing countries is on the whole a very narrow one indeed. Both in government and private work, the lawyer is usually considered a technician and generally appears prepared to accept restriction to a technician's role. The government lawyer rarely participates in the policy making process and frequently even cedes the task of legislative drafting to government administrators. The private lawyers rarely acts [sic] as a general business advisor and generally does not participate significantly in negotiation on behalf of his client. 58

The Americanism of this emphasis is made apparent by the reaction of a German-trained IMF lawyer of the time, who argued that there was no real reason to think that it was their doctrinal legal training that was keeping Third World lawyers excluded from policy making process, while foreign lawyers were allowed

and Comparative Law, American Bar Association (August 7, 1966), in 112 CONG. REC. 19, 25449-50 (1966) (quoted in Ballmann, infra note 59, at 201).

57 Id.

58 Id. 
in. 59 The problem was more the other way around: until Third World governments brought local lawyers into the policy making process, for which he thought many were already ready, those lawyers would never develop the practical skills that would allow them to contribute meaningfully to that process. ${ }^{60}$ The idea that "Americanizing" legal education would solve this problem was misguided, as

No law school would attempt to teach its students how to draft central banking, commercial banking or exchange control legislation. This kind of specialization will have to develop as part of a lawyer's future professional career in government service, and it can only develop if the lawyer is given a chance to acquire an intimate knowledge of the policy considerations which determine the substance of the law. ${ }^{61}$

Development assistance was predominantly bilateral during the modernization era, rather than flowing through international organizations such as the United Nations or the international financial institutions, ${ }^{62}$ a happy coincidence considering the society-wide scope of the modernization approach. While advocating economic law reforms is inherently political, attempting to "modernize" entire societies seems obviously more so. But attempts have been made to limit political interference by international institutions such as the IMF, the World Bank and the

59 See Franz Ballmann, Legal Technical Assistance of the International Monetary Fund to Member Countries Through Economic Development Legislation, 3 J.L. \& EcoN. DEV. 197, 202 (1968) ("[T]here is probably less of a problem with legal education because universities can only provide a thorough foundation in law and economics in more general terms.").

60 See id. (arguing that the expertise of local lawyers is essential to policymaking in developing countries).

61 Id.

62 Trubek, supra note 55, at 75. The International Monetary Fund was involved in legal technical assistance by the late 1960s, however, though at that point the IMF was less demanding of its borrowers. See Ballmann, supra note 59 (discussing the assistance provided by the IMF at the time). As for the choice between the United Nations and institutions such as the World Bank or the IMF, some suggest that developed countries shifted the development agenda away from the UN and to the IFIs because they were easier to influence. See John Toye, Changing Perspectives in Development Economics, in ReTHINKING DEVELOPMENT ECONOMICS 21, 32 (Ha-Joon Chang ed., 2003) (discussing development assistance as related to international financial institutions). 
Asian Development Bank, ${ }^{63}$ and although such textual constraints are open to interpretation, ${ }^{64}$ it is clear that their presence at least shapes the law and development rhetoric of the IFIs. ${ }^{65}$ But despite the fact that the bilateral nature of the law and development programs meant no international law limits on potential political implications, the Cold War context provided recipient governments with at least a partial shield against unwelcome political interference, turning to the Soviets. ${ }^{66}$ With the collapse of the socialist world, developing countries have no way to "enforce" the non-political interference norm, and this fact, together with the rise of new institutional economics, meant that even the IFIs no longer had to take the norm very seriously. ${ }^{67}$

\subsection{Dependency and World Systems Theory: Modernization's Discontents}

The decline of the modernization ethos is a complex story that played out differently in various locations and in various academic fields, ${ }^{68}$ but one key area of dissatisfaction with the approach had to do with its tendency to trust in the Third World state as representing the public interest, defined as socially responsible economic development and pluralist democratic governance. 69 Looking at the issue this way highlights an important parallelism between attacks on modernization theory from the left and the right, which also links them both to contemporaneous developments in the United States. By the 1970s, neoclassical economists interested in development issues were developing their attack on state intervention as inefficient and an excuse for rent-

63 See infra notes $118-19$.

64 Id.

65 The IMF was clearly aware of this issue, at least in the 1960s. See Ballmann, supra note 59, at 198 ("The aim is always to achieve technical professional quality as opposed to a certain political result.... [P]olitical considerations are ... the domain of the government; they are not the concern of the experts.").

66 For many modernization theorists, the Soviet Union did in fact constitute a modern society, as it appeared to be highly industrialized and urbanized, with a government that had succeeded in penetrating the society to mobilize the populace. See GilmAN, supra note 38 , at 148-49.

67 See infra notes 118-19.

68 See GILMAN, supra note 38, at 203-40.

69 See Henry J. Steiner \& David M. Trubek, Brazil-All Power to the Generals, 49 FoREIGN AFF. 464 (1970) (providing an example from the field of law and development). 
seeking by government functionaries. ${ }^{70}$ This movement had direct links to the economic attack on regulation being developed by conservative, free-market economists in the United States, ${ }^{71}$ which helped spark a revolution in American public law. ${ }^{72}$ From the left, meanwhile, came the charge that the Third World state was captured by international capital and in league with local comprador elites, ${ }^{73}$ a charge that shares much with the contemporaneous claims from the American left that United States regulatory agencies were captured by the industries they were supposed to be regulating in the public interest. ${ }^{74}$ The neoclassical attack will be discussed in connection with the rise of the neoliberal ("Washington Consensus") rule of law, Section 2.3, below, while the following passages address attacks on modernization thinking from the left, which came in the form of dependency theory and world systems analysis. ${ }^{75}$

Dependency theory is typically associated with economists Raul Prebisch, Andre Gunder Frank, ${ }^{76}$ and their followers, while world systems analysis is associated with the historian Emmanuel

70 See, e.g., Anne O. Krueger, The Political Economy of the Rent-Seeking Society, AM. ECON. REV., Jun. 1974, at 291, 291-94 (examining the effects of government restrictions on rent-seeking).

71 See, e.g., George J. Stigler, The Theory of Economic Regulation, BELL J. ECON. \& MGMT. SCI., Spring 1971, 3, at 10-13 (critiquing government regulation of industry).

72 See, e.g., Thomas W. Merrill, Capture Theory and the Courts: 1967-1983, 72 CHI.-KENT L. REV. 1039, 1039-44 (1997) (describing a sixteen year period of remarkable common-lawmaking during which the federal courts "significantly transformed the law of administrative procedure").

73 See Toye, supra note 62, at 30-31 (reviewing the rise of neoliberalism).

74 See Merrill, supra note 72 (finding that the bias of agencies towards the industries they regulate is regarded as a pervasive problem).

75 See J. Samuel Valenzuela \& Arturo Valenzuela, Modernization and Dependency: Alternative Perspectives in the Study of Latin American Underdevelopment, 10 COMP. POL. 535 (1978) (comparing and contrasting the "dependency" and "modernization" perspectives). It is useful in this context to remember here that the "developmental state" scholarship that grew out of studies of Northeast Asia in the late 1970s was a reaction to the fact that in their attacks on modernization theory and the Third World state neither the right nor the left paid much attention to the role of the state in Northeast Asia. See, e.g., Amsden, supra note 31 (suggesting that the historical roots of small and medium-sized enterprises (SMEs) and regional decentralization of industry make the policies of Taiwan's economic development difficult to reproduce elsewhere).

76 See, e.g., Andre Gunder Frank, The Development of Underdevelopment, MONTHLY REVIEW, Sept. 1966, at 17; Andre Gunder Frank, The Sociology of Development and the Underdevelopment of Sociology, CATALYST, Summer 1967, at 20. 
Wallerstein. ${ }^{77}$ Though there are important differences between the dependency and world systems approaches, the two can be said to share the following basic views. First, both assign nations of the world to categories such as "core/periphery," "center/periphery," or "dominant/dependent," based upon their wealth and power. The core is made up of advanced industrialized nations, the periphery is made up of poor states which often rely on commodity exports for their foreign exchange earnings, while the "semi-periphery" is somewhere in between. This international division of labor, the "international system," favors some countries to the detriment of others and limits the development possibilities of the subordinate economies. This ultimately results in "a situation in which the economy of a certain group of countries is conditioned by the development and expansion of another economy, to which their own is subjected." 78

The modernization approach had seen integration into the international economic order as basically benign and desirable, though its focus on state-supported industrialization certainly reflected doubt that Ricardian comparative advantage alone would enrich developing countries. While this doubt was in the air in the $1940 \mathrm{~s}, 79$ it became formalized around 1950 in the Prebisch-Singer thesis, which holds that the terms of trade favor manufacturing over commodities in the long term, so that for a developing country to simply rely on its comparative advantage to export commodities, while importing manufactured goods, would be a losing proposition. ${ }^{80}$ But while modernization theory counted on the nation state to play the necessary, interventionist role of fostering industrialization, the dependency theories that followed doubted that the international forces which consign nations to the "periphery" will allow Third World states to play such a constructive role. These forces, which include international commodity markets, the interests of multinational corporations, as

77 Immanuel Wallerstein, The Rise and Future Demise of the World Capitalist System: Concepts for Comparative Analysis, 16 COMP. STUD. SOC'Y \& HIST. 387 (1974) (describing world systems analysis).

78 Theotonio Dos Santos, The Structure of Dependence, in READINGS IN U.S. IMPERIALISM 225 (K.T. Fann \& Donald C. Hodges eds., 1971).

79 John Toye \& Richard Toye, The Origins and Interpretation of the PrebischSinger Thesis, 35 HIST. POL. ECON. 437, 440 (2003) ("By the time of World War II, the belief had already begun to gain ground that agricultural countries had better reasons than industrial ones to be pessimistic about their economic prospects.").

80 Id. at $437-38$. 
well as the interests of Third World comprador elites, will instead conspire to maintain and enforce the international division of labor captured in the core-periphery image. According to Andre Frank, the relationship between the satellite underdeveloped countries and the now developed metropolitan countries is an essential part of the capitalist system.

If one understands the problem in this way, there is little sense in modernization's strategy of replicating within developing countries the institutions of "modern" societies since modernization was never based on internal characteristics but was instead achieved through the exploitation of poor countries. Focusing, à la Weber, Parsons, and their followers, ${ }^{81}$ on the internal characteristics of developing countries to explain why they are poor is just a form of blaming the victim, and even if a developing country succeeded in replicating modern institutions internally, this would do nothing to change the country's place in the international order.

While there clearly was an orthodoxy of law and development that corresponded to modernization theory, it is not surprising that no such orthodoxy can be linked to dependency and world systems thinking, which arose in critical reaction to modernization theory, and to the Western exploitation of the developing world with which modernization theory was tainted. Dependency and world system thinking, as facets of a broader collapse of modernization thinking, clearly affected those involved in law and development activities. ${ }^{82}$ However, the message these approaches would impart would be a deep skepticism towards legal development assistance targeted at domestic legal systems. Some in the law and development community influenced by the dependency critique retained an interest in law reform, but turned their attention from national law reforms to reforming the international legal order, a movement associated with the New

${ }^{81}$ The institutional approach of Douglass North, for example, would be open to the same critique. See infra notes 84,86, 239, 250, 251 and accompanying text.

82 See Trubek \& Galanter, supra note 38, at 1063 ("Many scholars in the area have encountered difficulties defining the nature of their work or explaining its social utility."); see also JAMES A. GARDNER, LEGAL IMPERIALISM: AMERICAN LAWYERS AND FOREIGN AID IN LATIN AMERICA (1980); Francis G. Snyder, Law and Development in the Light of Dependency Theory, 14 LAW \& SOC'Y REv. 723 (1980) (discussing the methods, presuppositions and concepts of the principle theoretical writings on underdevelopment and dependency). 
International Economic Order movement of the 1970s.83 It was in this way that some law reform advocates maintained a link with development economics as some in that field also turned their attention to reforming the international economic system.

\subsection{The Washington Consensus Rule of Law}

The next real orthodoxy that arose following the demise of the modernization movement was the rule of law orthodoxy associated with the Washington Consensus and the energetic neoliberalism of the 1990s. This was the orthodoxy developed to frame and justify the massive law and development agenda that grew out of the collapse of the Soviet Union, and which accompanied the economic globalization of the 1990s. References to economist Douglass North's designation of law as an "institution" with important economic implications ${ }^{84}$ helped justify legal reform initiatives that went far beyond the scope of prior IFI initiatives, and the rule of law became the umbrella concept used to rhetorically unify a wide range of legal development initiatives. ${ }^{85}$

While economic thinking about development generally had moved on after the demise of modernization, much of it towards free-market solutions, some in the direction of the dependency critique, it was some time before a new law and development orthodoxy arose. This was likely the result of several factors, but among them two seem especially important. First, one would have to count the tendency, prior to the rise of "new institutional economics," ("NIE") for mainstream economics not to think much about private law, essentially assuming smoothly functioning legal systems as the background for theorizing about markets. ${ }^{86}$ As

83 Scott Newton, The Dialectics of Law and Development, in Trubek \& Santos, supra note 3, at 174, 182-87 (discussing the "Commonwealth school" that arose, informed by dependency theory, in reaction to the modernization orthodoxy).

84 See DOUGLASS NORTH, INSTITUTIONS, INSTITUTIONAL CHANGE, AND ECONOMIC PeRfoRmANCE (1990) (providing an analysis of the nature and role of institutions which has become widely cited in law and development literature).

85 See Upham, Mythmaking in the Rule of Law Orthodoxy, supra note 13, at 1 ("The new development model contends that sustainable growth is impossible without the existence of the rule of law: a set of uniformly enforced, established legal regimes that clearly lays out the rules of the game."); Ohnesorge, supra note 41 , at 1 ("The 1990s saw a remarkable revival of the term 'Rule of Law' in legal and political discourse in the U.S., and internationally.").

86 See Ronald Coase, The New Institutional Economics, 88 AM. ECON. REv. 72 (1998) (describing trends in economic theory that have developed since the term 
neoclassical economics came to dominate development thinking, attention shifted away from the "process" or "systemic" concerns important to the modernization era, such as building modern government institutions and ensuring that legal systems could effectively transmit government policies, to a substantive concern with free markets and limited government.

Two separate currents seem to have converged in the late 1980s to bring law and legal institutions back into the development picture. One was the increasing influence of NIE, which brings institutional structures and processes, explicitly including law, back into economic theorizing. The second was the fall of the Berlin Wall and the collapse of the socialist world, which had two effects. First, it quite suddenly presented the development community with the problem of how to nurture market economies in Eastern and Central Europe, the Baltics, and Central Asia, where legal systems were geared to socialist rather than capitalist economics, ${ }^{87}$ and second, it left developing countries with nowhere to turn for assistance except the U.S.-dominated West, in which views on economics and the role of the state in society had taken a strong turn towards the market. 88

"new institutional economics" was coined); Douglass C. North, Institutions and Economic Theory, 36 AM. ECONOMIST 3 (1992).

87 See Cheryl W. Gray, In Search of Owners: Privatization and Corporate Governance in Transition Economies, WORLD BANK RESEARCH OBSERVER, Aug. 1996, at 179,181 :

[Formerly socialist economies must] establish the institutions of a private market economy. Socialism either crippled or reoriented these institutions to reflect the goals of central planners. Legal frameworks defining property rights, private contract regimes, fiduciary liability, dispute resolution mechanisms, and rules of entry and exit for private firms atrophied. Courts lost much, if not all, of their independence as well as their role as adjudicators of commercial disputes and enforcers of commercial laws. Banks lost their independent monitoring role over firms and became instead passive funnels for channeling state funds. "Watchdog" institutions that provide critical information for markets to function, such as credit-rating and consumer protection services, accounting and legal professions, and independent journalism, had neither reason nor permission to exist. Finally, socialism inhibited (indeed, often classified as illegal) the development of basic norms and ethics of market conduct and fiduciary responsibility on which so much behavior in advanced market economies implicitly rests. These laws, organizations, professions, and commercial norms must now be rebuilt, sometimes from scratch.

88 Countries wanting to reform within a basically socialist order might turn to China, but China has not shown great interest in exporting its law reform 


\subsubsection{The Economics of the Washington Consensus}

Described very simply, NIE refers to the branch of economics that concerns itself with the ways that economic behavior, whether by individuals or by firms, is affected by the institutional setting in which actors find themselves. ${ }^{89}$ The approach is sometimes traced to Ronald Coase's 1937 article, The Nature of the Firm, ${ }^{90}$ which argued that a firm's decision to produce an input itself, or instead to obtain it by contracting with an outside producer, should be understood as based upon a consideration of the "transaction costs" involved, mainly the costs involved in creating and enforcing the purchase contract. ${ }^{91}$ Coase's thesis was that a firm will continue to bring production of inputs in-house until the cost of doing so exceeds the cost of obtaining them on the market, and because transaction costs are determined by the institutional environment in which the firm exists, it is this institutional environment that determines in a very real way the scope of any particular firm. From this insight grew the field of "transaction cost economics," associated with Oliver Williamson and others, and the broader NIE tradition. It is important to note that NIE shares with modernization scholarship the goal of unifying social science under one paradigm. But while Talcott Parsons, at least, dreamed of a unified social theory in which economics would provide but one source of knowledge about human behavior, ${ }^{92}$ NIE's distinctly anti-Parsonian aspiration is to unify the social sciences under the hegemony of economics. ${ }^{93}$

experience, and countries in Southeast Asia, such as Vietnam, tend to be ambivalent about Chinese influence.

89 See Coase, The New Institutional Economics, supra note 86.

90 R. H. Coase, The Nature of the Firm, 4 ECONOMICA 386 (1937).

91 Id. at 390-92.

92 See GILMAN, supra note 38, at 79-84; Parsons, supra note 45, at 339-46 (clarifying the concept "evolutionary universal" -innovation which gives the possessor a substantial increase in general adaptive capacity-and citing four features of human cultural and social organization that are prerequisites for sociocultural development); Trubek, supra note 16, at 720-52 (distilling Max Weber's contribution to law and development theory).

93 See Iris Center at the University of Maryland, http://www.iris.umd.edu/Reader.aspx?TYPE=FORMAL_PUBLICATION\&ID= a2113878-d64a-40f1-a570-215d2a810606 (last visited Apr. 8, 2007) (reviewing A NEW INSTITUTIONAL APPROACH TO ECONOMIC DEVELOPMENT (Mancur Olson \& Satu Kahkonen eds., 2001)) ("Modern economics has had a deep influence on thinking in other social sciences, leading to the theoretical integration of all the social sciences under an overarching paradigm."). 
Related to NIE is the "public choice" tradition in economics, which applies the methods of microeconomics to the study of real, especially political, institutions. ${ }^{94}$ Public choice sentiment was already well represented in development economics through the work of Ann Krueger and Jagdish Bhagwati, among others, whose attacks in the 1970s on rent-seeking by Third World governments constituted part of the rejection of the modernization approach. ${ }^{95}$ Although NIE and public choice might be thought of as separate traditions, one studying the behavior of institutions, the other studying how institutions structure individual behavior, this is not the place to disentangle the two. People who are important to the two traditions and to their impact on law and development, North and Mancur Olson ${ }^{96}$ in particular, are connected to both traditions. In addition, one can say that both started with a strong commitment to "methodological individualism" and rational actor assumptions, ${ }^{97}$ although broadening the definition of an institution to include social and cultural norms, as both Coase and North do,98 loosens the rational actor assumption from its traditional mooring in narrow economic terms. Second, in their prescriptive modes, at least as absorbed by the law and development literature, they combined to support a predictably neoliberal set of policies, focusing on deregulation, privatization, and maximum play for the markets. It could be said that NIE opened the door for economists to concern themselves with pretty much any aspect of a legal system, while the public choice approach helped convince them that governments should not do much more with these legal

94 See generally Daniel A. Farber \& PhiliP P. FRICKEY, LAW AND PUblic CHOICE: A CRITICAL INTRODUCTION (1991) (presenting five main reasons why the issues raised by public choice are critically important); JERRY L. MASHAW, GREED, CHAOS, \& GovernanCE: Using Public Choice to IMPRove Public LaW (1997) (examining the challenges and issues that arise under positive political theory).

95 See Toye, supra note 62, at 31 (discussing rent-seeking activities); Krueger, supra note 70, at 291-94 (examining the adverse effects of government restrictions on rent-seeking).

96 See A New Institutional Approach to ECONOMiC Development, supra note 93 (using examples from developing countries to explore the interaction between economics and other social sciences). Olson co-founded the University of Maryland's IRIS Center, a major participant in United States governmentfunded law and development projects which operates within the NIE rubric.

97 On NIE, see, for example, Coase, supra note 86 . On public choice, see FARBER \& FRICKEY, supra note 94; MASHAW, supra note 94.

98 For Coase the relevant institutional matrix of a particular country includes, "its legal system, its political system, its social system, its educational system, its culture, and so on." Coase, supra note 86 , at 73. 
systems than establish rules respecting property and contract, along with courts to enforce them.

\subsubsection{The New Law and Development of the Washington Consensus}

With NIE and public choice economics providing the intellectual framework, the specific law and development orthodoxy that developed during this period could be thought of as a Washington Consensus or neoliberal rule of law. ${ }^{99}$ In accord with NIE thinking, but also certainly responding to the demand for systemic legal reform presented by the transitioning socialist legal systems, the orthodoxy sought to provide the answer to legal system needs from bottom to top. ${ }^{100}$ Private property rights were at the center of the approach, making demands both on private and public law to provide clear, predictable "rules of the game" within which private economic activity could take place. On the private law side, the orthodoxy focused on providing clear and enforceable private property rights, and rules-based contract law that would facilitate trade.101 Courts and court reform become very important in this orthodoxy, but the concern seemed to be mainly with how to make courts "user friendly;" how to make them effective, low-transaction-cost enforcers of private rights. ${ }^{102}$ Legal professions reappeared, but, like courts, mainly as reducers of the costs of transacting. 103

Private property is also protected by criminal law, of course, and economists demonstrated mathematically that law and order

99 See Ohnesorge, supra note 40 (questioning the rule of law-economic rhetoric of the World Bank as it relates to development in Northeast Asia). A thorough statement of the approach can be found in WORLD DEVELOPMENT REPORT 1996: FROM PLAN TO MARKET 85-97 (The World Bank 1996). For a concise example, see Cheryl W. Gray, Reforming Legal Systems in Developing and Transition Countries, FIN. \& DEV., Sept. 1997, at 14, 14 ("Improving the functioning of legal institutions is an essential component of economic development.").

100 This claim of a mandate for total reform is apparent in the statement by the principal economist in the World Bank's Policy Research Department. Gray, supra note 87 , at 181 .

101 See WORLD BANK, supra note 99, at 87 ("Where the rule of law is in force, laws are applied fairly, transparently, and evenhandedly to all ....").

102 See Gray, supra note 99, at 14 ("If a dense and efficient network of commercial relationships is to flourish in an economy, it needs a credible and lowcost formal legal process to which aggrieved parties can turn when all else fails.").

103 See WORLD BANK, supra note 99, at 93 (discussing the various roles played by judicial institutions). 
is important to a functioning economy, though a bit of re-branding turned "law and order" into the rule of law. ${ }^{104}$ More importantly, though, private property is also protected by public law, and it was here that public choice economics and the economics-based critique of regulation made their greatest impact on the law and development orthodoxy. In looking at references to constitutional law in the literature of the time, the main concern seems to have been with trying to overcome the "credible commitments" puzzle: how to engineer constitutional law so that the same governments that were creating and defining private property rights would not subsequently be able to "infringe" them. ${ }^{105}$ With respect to administrative law, the main claim of the orthodoxy was again that economic development required a system of administrative law that could tightly constrain government actors within a system of clear rules, which would facilitate freedom of action by private economic actors, as well as reduce opportunities for rent-seeking (which would also be reduced by deregulation). This reflected a Hayekian commitment to maximizing the clarity and predictability of the regulatory environment, thus maximizing the extent to which private actors can plan their activities, ${ }^{106}$ as well as reflecting the public choice position that the incentives of bureaucrats lead to rent-seeking and bureaucratic imperialism. ${ }^{107}$

In addition to claiming that this highly protective framework for private property and contract enforcement was crucial for economic development, the orthodoxy included strong claims with respect to several specific areas of law. Broadly defined and vigorously enforced intellectual property rights, for example, were said to be important for economic development, as without them locals would not invent, and foreign intellectual property owners would not invest or make their technology available through

104 See Stephen Knack \& Philip Keefer, Institutions and Economic Performance: Cross Country Tests Using Alternative Institutional Measures, 7 ECON. \& POL. 207 (1995) (quantifying the relationship between institutions, economics and growth).

105 WORLD DEVELOPMENT REPORT 1997: THE STATE IN A CHANGING WORLD 99102 (The World Bank, 1997).

106 For Hayek, the rule of law meant that "the government in all actions is bound by rules fixed and announced before-hand-rules which make it possible to foresee with fair certainty how the authority will use its coercive powers in given circumstances and to plan one's individual affairs on the basis of this knowledge." Friedrich A. HAYEK, THE ROAD TO SERFDOM 72 (1944).

107 See, e.g., William A. NiskanNen, Bureaucracy and Representative GOVERNMENT (1971) (developing a theory of supply by bureaus). 
licensing. ${ }^{108}$ Developing countries needed to have effective competition law so markets would be competitive, ${ }^{109}$ and effective insolvency regimes to make sure creditors could enforce their rights. ${ }^{110}$ Effective corporate law protecting shareholders was also claimed to be important, either to protect minority from majority shareholders, ${ }^{111}$ or to protect shareholders from managers based upon the assumption of a separation of ownership and control. ${ }^{112}$

It is obvious that much of this reform energy was highly instrumental, directed not merely at "reforming" legal systems, whatever that might mean, but at getting them to meet substantive performance criteria along specified dimensions. The goal was not just some general level of performance, but to achieve "a wellfunctioning legal system in a market economy," which required "a supply of market-friendly laws, adequate institutions to implement and enforce them, and a demand for those laws from market participants." 113 The idea seems to have been to set in motion a virtuous cycle, in which demand and supply would feed off one another until the market-friendly neoliberal Rule of Law was achieved. Demand was to be supplied via privatization in former socialist countries such as Russia, ${ }^{114}$ so the orthodoxy functioned as a justification for rapid, wholesale privatization, which the neoliberal rule of law would have rendered irreversible, had the model worked. As will be discussed below, that goal, like the idea of a "modern" society, tended to reproduce an idealized picture of how law operated in the United States or perhaps Western Europe, but was not well supported by the roles that law played in

108 See Ohnesorge, supra note 40, at 96, 103.

109 See WORLD BANK, supra note 99, at 92-93 (discussing competition laws and barriers to trade).

110 See id. at 91-92 (analyzing an effective bankruptcy code).

111 See, e.g., Gray, supra note 99, at 15 (describing the extensive system of shareholder protections built into the 1995 Russian company law to allow minority shareholders to protect themselves against dominant shareholders).

112 See, e.g., Gray, supra note 87, at 2 ("For small firms this is straightforward . .. the owners and managers are one and the same. For large firms, however, the likely separation of ownership and management creates the need for monitoring.").

113 See Gray, supra note 99, at 14-15.

114 See Katherine Hendley, Rewriting the Rules of the Game in Russia: The Neglected Issue of the Demand for Law, 8 E. EUR. CONST. REV. (Fall 1999) available at http://www.law.nyu.edu/eecr/vol8num4/feature/rewriting.html (discussing the attitude of citizens to Russia's recent embrace of the rule of law) (last visited Apr. 8, 2007). 
Northeast Asia's successful market economies. Before that discussion, however, it is important to note the wrapping in which this gift came to the world, a highly particular rule of law rhetoric.

There are several aspects of the turn to rule of law rhetoric that are worth reflecting upon, ${ }^{115}$ but for purposes of this Article the most important is the way it was used to present a fairly particular set of substantive goals as a general, neutral legal framework. In this the relationship between rule of law rhetoric and NIE is quite clear. NIE tells us that the functioning of an economy will depend upon the effectiveness of its institutional matrix, while rule of law rhetoric tries to fill in the legal component of that effective framework.116 At this level of generality they both tend to depoliticize what actually needs to happen to "reform" institutions, especially law, which is that somebody needs to change a whole raft of rules, both general legal rules and rules respecting legal actors such as courts and lawyers, and that as a result of those rule changes there are going to be winners and losers. The extent to which the establishment of any particular vision of the rule of law shifts power in society is often ignored or underestimated; the neoliberal rule of law, for example, would radically redistribute power away from the executive branch, administrative agencies, and at times legislatures, in favor of the courts and private actors able to wield market power. Because the earlier law and development era had been dominated by bilateral assistance efforts, whether national or private, the problem of political interference had a different valence. ${ }^{117}$ Now that the IFIs were taking a much larger role they had to deal with the fact that their foundational documents tell them they are supposed to refrain from political interference, and invoking the rule of law appears to have been part of the strategy.

The World Bank and the IMF differ formally in this regard, though whether that matters is questionable. The IMF Articles of Association contain no explicit general prohibition against political interference, though IV.3.b does prohibit political considerations in

115 See generally John K.M. Ohnesorge, Rule of Law, ANN. REV. LAW SOC. SCI. (forthcoming 2007).

116 See Ohnesorge, supra note 40 (evaluating economic claims for rule of law).

117 See, e.g., John Henry Merryman, Law and Development Memoirs I: The Chile Law Program, 48 AM. J. CoMP. L. 481 (2000) (discussing Chile program in the 1960s); GARDNER, supra note 82 at $282-88$ (describing the relationship between American "legal missionaries" and Third World legal actors). 
connection with certain decisions. The IMF legal staff interprets its Articles like a corporate charter, however, looking to the Articles, particularly Article 1, to assess whether a proposed activity would be ultra vires. As former IMF General Counsel Francois Gianviti recently noted, however, because the IMF has ultimate authority to interpret its own "charter," the openness of the text leaves no doubt that this is a matter of self-policing, ${ }^{118}$ constrained in the end by power politics. The World Bank, on the other hand, has to deal with Article IV, Section 10 of the IBRD Articles of Agreement, which provides:

The Bank and its officers shall not interfere in the political affairs of any member; nor shall they be influenced in their decisions by the political character of the member or members concerned. Only economic considerations shall be relevant to their decisions, and these considerations shall be weighted impartially in order to achieve the purposes stated in Article 1.

In the early 1990s World Bank General Counsel Ibrahim Shihata issued a legal opinion that essentially defined this prohibition away, at least with respect to law and development activities. ${ }^{119}$ Signaling that the Bank's lawyers were not going to get in the way of a new law and development agenda dominated by NIE thinking, Shihata characterized the "rule of law" as basic to the "governance" structure that is necessary for a successful economy.120 This seems to sanction any law and development project that could be cast as furthering the rule of law, which turns out to be a pretty big set. In a memorial for Mr. Shihata, IMF Senior Counsel Robert Effros singled out this memo as important in legitimating IFI law and development activities, 121 demonstrating a strange commitment to formal legal regularity by

118 See Francois Gianviti, Evolving Role and Challenges for the International Monetary Fund, 35 INT'L LAW. 1371, 1374 (2001) (discussing the broad language and interpretive power of the IMF).

119 See Robert C. Effros, The World Bank in a Changing World: The Role of Legal Construction, 35 INT'L LAW. 1341, 1345-47 (2001) (evaluating Dr. Sihata's view of law and development).

120 See id. (discussing law as the formal instrument of order in society); Frank K. Upham, Comment, Speculations on Legal Informality: On Winn's "Relational Practices and the Marginalization of Law", 28 L. \& SOC'Y REV. 233, 234 (1994).

121 See Effros, supra note 119, at 1345 (discussing the importance of Dr. Sihata's opinions). 
organizations that, at least on this issue, are really checked only by power, not by law.

Although many criticisms have been leveled at the Washington Consensus and the neoliberal rule of law orthodoxy that accompanied it, it would be a mistake to believe that orthodoxy was repudiated as dramatically as was the modernization approach. Instead, as evidence mounted that the world was more complex than that approach contemplated, and that many people in poor countries were not necessarily benefiting from neoliberal economic and legal reforms, the neoliberal rule of law seemed to evolve in two distinct directions. Those two strains, "protoorthodoxies" of law and development, represent the dominant discourse today.

\subsection{The Legal Origins of Orthodoxy: Law and Finance, Legal Origins, and the Common Law-Civil Law Divide}

The first of the two current proto-orthodoxies is based in large part upon what is known as the "legal origins," or "law and finance" literature, which grew out of work in the mid-1990s by a group of financial economists interested in the effects of legal systems on financial system performance. ${ }^{122}$ Their initial focus was on financial markets and minority shareholder protections in legal systems around the world, hence the name "law and finance," but the legal origins approach is now much broader than those initial beginnings. ${ }^{123}$ The basic method of the literature is formal and analytic, seeking to test statistically various hypotheses concerning relationships between legal system attributes and economic performance, differences between common and civil law traditions being one major example.124 Various aspects of national legal systems are given numeric scores, which are then combined with

122 Rafael La Porta et al., Legal Determinants of External Finance, 52 J. Fin. 1131 (1997); Rafael La Porta et al., Law and Finance, 106 J. POL. ECON. 1113 (1998); Mark J. Roe, Legal Origins, Politics, and Modern Stock Markets, 120 HARV. L. REV. 460, 470 (2006).

123 See Ohnesorge, supra note 42 , at 487 (explaining that new legal origins literature takes into account "broader social phenomena" such as economic growth); Edward L. Glaeser \& Andrei Shleifer, Legal Origins (Harv. Inst. of Econ. Research, Paper No. 1920, 2001), available at http://ssrn.com/abstract $=267852$. See also Emma Phillips, The War on the Civil Law: The Common Law as a Proxy for the Global Ambition of Law and Economics, WIS. INT'L L. J. (forthcoming 2007).

124 See Kenneth W. Dam, Legal Institutions, Legal Origins, and Governance (The Chicago Working Paper Series, Working Paper No. 303, 2006) (introducing his paper by comparing common and civil law). 
scores from other countries and used as the data for statistical testing of hypotheses concerning legal systems and socio-economic outcomes. ${ }^{125}$

Whatever this literature's ultimate contribution to science, 126 it is also serving as an important source of policy prescriptions, as is clear from the fact that it is having a major impact within at least some at the World Bank.127 The Bank's "Doing Business" reports, ${ }^{128}$ which have been produced annually since 2004, presents this "disciplinary" side of the legal origins/law and finance literature, converting its scholarly claims into a program for encouraging private sector growth in developing countries. Three of the original 'LLSV' authors, Rafael La Porta, Florencio Lopez-deSilanes, Andrei Shleifer, have been closely involved in the Doing Business, as has Simeon Djankov, another prolific 'legal origins'

125 See Holger Spamann, On the Insignificance and/or Endogeneity of LaPorta et al.'s 'Anti-Director Rights Index' under Consistent Coding (Harv. L. Sch. John M. Olin Ctr., Working Paper No. 7, 2006) (recoding the Antidirector Rights Index).

126 The approach has generated a good deal of skepticism. See, e.g., Roe, supra note 122, at 464 (explaining why the consideration of legal systems may not be as important as once thought for policymaking); Spamann, supra note 125, at 2 (finding a less significant difference between civil and common law systems after correcting the ADRI analysis of La Porta and Djankov); Dam, supra note 124 (attributing a greater importance to governance than legal systems in assessing economic growth); Phillips, supra note 123; Allen et al., infra note 131, at 2 (citing China as a notable counterexample of the studies of La Porta et al., boasting one of the fastest growing economies despite poor legal and financial systems); Graff, infra note 132, at 8 (concluding that reasonable explanatory alternatives to the Law and Finance Theory exist); Ohnesorge, supra note 42, at 490 (using China as an example of how sophisticated legal systems are not a necessary prerequisite to economic growth); Udo C. Braendle, Shareholder Protection in the U.S.A. and Germany: On the Fallacy of LLSV 3 (Univ. of Manchester Sch. of L.) available at http://www2.jura.uni-hamburg.de/le/braendle.pdf (illustrating the weaknesses in the Law and Finance Theory through a comparative analysis between the legal systems of the U.S. and Germany); Mathias M. Siems, Legal Origins: Reconciling Law $\mathcal{E}$ Finance and Comparative Law 25 (Univ. of Cambridge Ctr. for Bus. Research, Working Paper No. 321, 2006) available at http://www.cbr.cam.ac.uk/pdf/ WP321.pdf ("The world-wide distinction between different legal families, such as common Law and (French, German, Nordic) Civil Law is not useful for [econometric] calculations....").

127 See Alvaro Santos, The World Bank's Uses of the "Rule of Law" Promise in Economic Development, in Trubek \& Santos, supra note 3, 253, 279-80 (describing the World Bank's efforts to encourage legal reforms through the creation of online resources for policymaking).

128 See, e.g., WORLD BANK, DOING BusInESS 2007: HOW TO REFORM (2007); WORLD BANK, DOING BUSINESS IN 2006: CREATING JOBS (2006); WORLD BANK, DOING BUSINESS IN 2005: REMOVING OBSTACles TO GROWTH (2005); WORLD BanK, DOING BUSINESS IN 2004: UNDERSTANDING REGULATION (2004). 
writer, and Peruvian economist Hernando De Soto. ${ }^{129}$ De Soto, famous for his claim that formalities and inefficiencies in the legal systems of developing countries keep the world's poor from enjoying the benefits of capitalism, 130 shares with the legal origins school an interest in assigning numerical values to legal system attributes, which can then be used in cross-country statistical analysis.

Again leaving aside the literature's value as social science, the relationship between its analytic and prescriptive aspects seems highly problematic. The vast majority of lawyers and legal academics will not have the expertise to question the statistical methods used by the authors of these studies, nor will they have the resources to challenge the data that provides the grist for the statistical mill. This is not to defend intellectual laziness, but to argue that as a source of policy prescriptions this literature seems particularly prone to reductionism. Looking to the specific claims of the literature, one would expect that equity markets would play an important role in financing the businesses that must lead development, and that legal protections for minority shareholders, which allegedly support such markets, would therefore also be important. ${ }^{131}$ Developing countries with common Law systems should therefore out-perform Civilian regimes, as common law regimes are associated with more developed equity markets and better protection of shareholders. ${ }^{132}$ Common law regimes should (2004).

129 WORLD BANK, DOING BUSINESS IN 2004: UNDERSTANDING REGULATION, at vii

130 See Hernando De Soto, The Other Path (1989); Hernando De Soto, THE Mystery of CaPITAL: Why CaptTALISM TRIUMPHS IN THE WEST aND FaILS EVERYWHERE ELSE (2000).

131 See Dam, supra note 124, at 8-9 (discussing the theory that financial market development predicts economic growth); La Porta et al., Legal Determinants of External Finance, supra note 122, at 5 (showing that countries with poorer investor protections have smaller and narrower financial markets); La Porta et al., Law and Finance, supra note 122, at 1116 (showing that common law countries generally have stronger protections for investors than civil law countries); Hideki Kanda, $A$ Note on the Law Matters Debate in Corporate Governance, 1 U. TOKYO J. L. \& POL. 87 (2004); Franklin Allen et al., Law, Finance, and Economic Growth in China (Univ. of Pa. Inst. for L. \& Econ. Research, Working Paper No. 03-21, 2004), available at http://ssrn.com/abstract=365641 (examining why China differs from other countries in the study of economic growth).

132 See Dam, supra note 124, at 8 (explaining La Porta's findings that common law regimes offered the greatest protection to shareholders and creditors); Allen, et al, supra note 131, at 1 ("One of the central results of the literature is that, countries with English common-law origin (French civil law origin) provide the strongest (weakest) legal protections to both shareholders and creditors."); 
also outperform Civilian regimes because governance in Civilian regimes is associated with high levels of formalities, seen as stifling private initiative and encouraging bureaucratic rent-seeking. ${ }^{133}$ Finally, Civilian adjudication is also inferior to common law, in that it is less able to bring about flexible refinements to legal rules that need to be changed, ${ }^{134}$ while Civilian regimes are also associated with generally Statist orientations, as opposed to the liberty-regarding, market-friendly common law. ${ }^{135}$ As should be apparent, there is an obvious overlap between the prescriptions of the legal origins approach and the earlier neoliberal rule of law orthodoxy, although the former is built upon a much more intimidating analytical foundation.

\subsection{The "Comprehensive Development" Rule of Law}

[E]nsuring human rights and freedoms is critical both for the development of the economy and for the social and political life of Russia. - Vladimir Putin ${ }^{136}$

While the legal origins literature offers a social-scientific basis for policy prescriptions that largely track the Washington Consensus, the current alternative proto-orthodoxy defines itself by its rejection of the Washington Consensus approach. Associated with the Comprehensive Development agenda developed in the late 1990s by James Wolfensohn when he was World Bank President, ${ }^{137}$ the Comprehensive Development

Michael A. Graff, Myths and Truths: The "Law and Finance Theory" Revisited (Swiss Inst. for Bus. Cycle Res., Working Paper No. 122, 2006), available at http://ssrn.com/abstract=881546 (analyzing the weaknesses in the law and finance theory).

133 See Rafael La Porta et al., The Quality of Government, 15 J. L., ECON. \& ORG. 222 (1999) (analyzing why larger governments perform better than small ones); Simeon Djankov et al., The Regulation of Entry (Harv. Inst. of Econ. Research, Paper No. 1904, 2001), available at http://ssrn.com/abstract=242738 (showing why regulation of start up firms actually increases corruption).

134 Simeon Djankov et al., Courts: The Lex Mundi Project (Nat'l Bureau of Econ. Research, Working Paper No. 8890, 2002), available at http://ssrn.com/abstract= 307127 (showing that formalism is greater in civil law countries).

135 Rafael La Porta et al., The Guarantees of Freedom (Yale Int'l Ctr. for Fin., Working Paper No. 02-05, 2002), available at http://ssrn.com/abstract=297145 (distinguishing English freedoms from American freedoms).

136 Peter Finn, Putin Touts Rule of Law to Reassure Investors, WASH. Post, Apr. 25, 2005, at A12.

137 James D. Wolfensohn, A Proposal for a Comprehensive Development Framework (January 21, 1999) (on file with author). 
approach predictably claims that legal system functioning is somehow intimately connected with development, but expands the claim to include human as well as property rights, and labor and personal rights laws as well as property, contract, bankruptcy and other commercial law. ${ }^{138}$ The following attempt to articulate a role for law reform in this broader development approach is typical:

Without the protection of human and property rights, and a comprehensive framework of laws, no equitable development is possible. A government must ensure that it has an effective system of property, contract, labor, bankruptcy, commercial codes, personal rights laws and other elements of a comprehensive legal system that is effectively, impartially and cleanly administered by a wellfunctioning, impartial and honest judicial and legal system. ${ }^{139}$

The rule of law, revived in the earlier Washington Consensus orthodoxy, is still the unifying rhetorical concept ("the sine qua non of development" in the words of the World Bank), but what developing countries need now is the "comprehensive development" rule of law, which:

$[P]$ revails where (1) the government itself is bound by the law; (2) every person in society is treated equally under the law; (3) the human dignity of each individual is recognized and protected by law; and (4) justice is accessible to all. The rule of law requires transparent legislation, fair laws, predictable enforcement, and accountable governments to maintain order, promote private sector growth, fight poverty, and have legitimacy. ${ }^{140}$

The World Bank's justification for a recent loan to the Venezuela Supreme Court loan, for example, is that an "improved judicial system will help enhance social and economic development

138 See Rittich, supra note 41 (explaining that the Comprehensive Development Framework requires attention be paid to issues such as "health, education, and gender equality" as well as "human rights, good governance, and the rule of law"); Ohnesorge, supra note 115, at 6 (emphasizing that the idea of due process and other natural human rights is inherent).

139 Wolfensohn, supra note 137.

140 WORLD BANK, INITIATIVES IN LEGAL AND JUDICIAL REFORM 2-3 (2004) (emphasis added). 
through improvement in the enabling environment for private investment and building confidence in the judiciary."141

As if designed to insulate the Bank from criticism from any quarter, this approach suggests that nearly anything we typically hope to get from a legal system-justice, fairness, equality, vindication of our rights - is somehow importantly related to development. NIE is still available for the proposition that all governance is somehow economic governance, ${ }^{142}$ and if the Washington Consensus rule of law spoke mostly to the neoliberal agenda for property rights and a non-interventionist state, the comprehensive development orthodoxy would fill in the other half of the circle by including a focus on "the social," as Kerry Rittich puts it. ${ }^{143}$

In doing so, the comprehensive development approach effectively returns to a "modernization" mentality with respect to the scope of the law and development agenda, as it revives the modernization tendency to define development much more broadly that simple economic development. Unfortunately, it also revives the modernizer's confident tone of standing at that Archimedian point from which power and knowledge can be deployed, via legal technical assistance, to remake (someone else's) society. For example, in a project involving a loan to the Supreme Court of Venezuela intended to help it improve itself, the Bank employed a "participatory" approach to designing the project itself, under which "stakeholders" are brought in to the process to help define goal and implementation, not merely as sources of information, as under the "external experts" approach. ${ }^{144}$ Although on the face of it this "stakeholder" approach seems obviously preferable to the "external experts" approach, it also looks like an attempt to preempt criticism of political interference

141 WORLD BANK, REPORT No. 17212-VE, PROJECT APPRAISAL DOCUMENT ON A Proposed Learning and INNOVATION LOAN IN THE AMOUNT OF US\$4.7 MILlion to THE RePUblic of Venezuela For a SUPREME COURT Modernization Project, at Annex 1, (1997) (emphasis added), available at http://www-wds.worldbank.org/ servlet/WDSContentServer/WDSP/IB/1999/09/17/000009265_3980217140241/

Rendered/PDF/multi_page.pdf.

142 Id. at 16 ("Lessons derived from 'New Development Economics' indicate that it takes time for modernizing societies to learn and internalize new rules of the game, and that institutional change is incremental.").

143 See Rittich, supra note 41, at 203-04 ("The [comprehensive development framework] pronounces that greater attention must now be paid to its 'social, structural and human' dimensions.").

144 WORLD BANK, supra note 141, at 18 (describing the participatory approach). 
by getting all the potential complaining parties to the table. This resembles the logic of negotiated rulemaking and other "new governance" experiments in the United States, 145 but our own experience suggests that this is no guarantee that outcomes will be perceived as legitimate, as parties that lose in this process are not likely to disappear quietly, unless their opportunity to object is somehow cut off. ${ }^{146}$ Another example can be found in USAID's Public Interest Legal Advocacy Project (PILAP) in Cambodia, ${ }^{147}$ which seems to have embraced an impact litigation model and sense of certitude right out of the 1960s.148

\section{TESTING THE ORTHODOXIES AGAINST NORTHEAST ASIA}

Although one could certainly contest aspects of the intellectual history outlined above, in its broad outlines the evolution of the law and development orthodoxies seems well-accepted. The next task, then, is to test the claims of those approaches against common understandings of the ways in which law functioned in Northeast Asia during the decades of rapid economic development. As will become clear, none of these theoretical approaches was developed empirically from study of Northeast Asia, nor do any of them fare very well when their claims are tested against Northeast Asia as a case study.

\subsection{Modernization (and its Discontents) Meet Northeast Asia}

Turning to the orthodoxy of the first law and development movement, the modernization approach of the 1960s, what do we find if we examine its claims through the lens of the Northeast Asian experience? Looking at the performance of Northeast Asia's

145 For an example of "new governance" literature, see Jody Freeman, Collaborative Governance in the Administrative State, 45 UCLA L. REV. 1 (1997).

146 See Cary Coglianese, Assessing Consensus: The Promise and Performance of Negotiated Rulemaking, 46 DUKE L.J. 1255 (1997) (drawing question to the value of formal negotiated rulemaking).

147 See Rule of Law: Success Stories: Legal Advocacy Project Wins Against Government Municipality in Cambodia, http://www.usaid.gov/our_work/ democracy_and_governance/technical_areas/rule_of_law/ss5.html (last visited Mar. 13, 2007) (describing a successful legal challenge by landowners).

148 PILAP selects legal cases that have strong potential to generate publicity and debate, and that demand broader accountability and respect for legal norms beyond the mere bounds of the case. Thus, while protecting individual clients' rights, PILAP also hopes to demonstrate the legal system's viability as an instrument to generate greater transparency and respect for the rule of law. Id. 
legal systems over the past several decades, there is no doubt that legal instrumentalism was ever-present in authoritarian South Korea and Taiwan, as well as in democratic Japan. Governing elites saw law as a tool they could use to control their societies, and retained levers with which they could exert political control over their judiciaries that extended even to decisions in particular cases. ${ }^{149}$ Northeast Asia thus took the instrumentalism of modernization's "liberal legality" one step further, as the instrumentalism envisioned by legal legality involved enacting general laws with instrumental purposes, but then leaving enforcement in particular cases up to the judiciary. Liberal legality essentially trusted that the judiciary would keep consequences and instrumental aims appropriately in mind, while still deciding individual cases in ways that would seem free from too strong an instrumentalist taint.150 Instead, even in Japan, where judicial independence was best institutionalized, individual judges were sometimes disciplined for particular decisions that displeased their superiors within the judicial bureaucracy.151 Although the noteworthy instances of such discipline were generally politically charged cases, especially in Japan, those cases were highly publicized, so any judge would have known of the possibility of punishment in case he decided "wrongly" according to those above. Law thus did not achieve the degree of autonomy called for even in the instrumental vision of liberal legality, and certainly not the level called for in later rule of law orthodoxies.

What about other aspects of the "modern" legal system called for in the 1960s? During their highest growth decades all of the countries in Northeast Asia limited the numbers of fully licensed

149 On Japan, see Frank K. Upham, Political Lackeys or Faithful Public Servants? Two Views of the Japanese Judiciary, 30 L. \& SOC. INQUIRY 421 (2005) (reviewing competing explanations of how Japanese judges are controlled). On Taiwan, see Hsiao-Ming Wang \& Leanne Fiftal Alarid, Judicial Sentencing Decisions in Taiwanese Economic Crimes: Consequences of Swift Justice," 35 L. \& SOC'Y REV. 607-25 (2001) ("By law, judges in Taiwan, like their American counterparts, should make their judgment independently. However, the promotion and transfer of Taiwanese judges are controlled by the Judicial Yuan, the highest authority of judicial administration in Taiwan. Hence, this chain of command may impact judicial decisionmaking...."); on Korea, see DAE-KYU YOON, LAW AND POLITICAL AUTHORITY IN SOUTH KOREA (1990).

150 Trubek \& Galanter, supra note 38 , at 1100.

151 See Upham, supra note 149, at 433 (citing studies showing that Japanese judges were often disciplined by the Secretariat for their acquittal decisions, regardless of legal inaccuracy). 
lawyers to a tiny fraction of what an American, at least, would consider normal. ${ }^{152}$ No doubt the existing lawyers tended to favor this protectionism, but at least in authoritarian Taiwan and Korea, one would not expect the legal professions to have sufficient political clout to obtain such a privileged position unless it also happened to benefit the political leadership, in which lawyers did not generally play a central role. In Korea and Taiwan, then, the extreme paucity of lawyers seems best explained as resulting from political choices to limit lawyers' social role and influence, while in the case of Japan the private interests of the bar or of industry probably played a bigger role in that policy outcome. In any case, though, lawyers in Northeast Asia even now have not become the free-ranging problem solvers of the modernization model, greasing the wheels of commerce one moment, protecting citizens from arbitrary state action the next. It is fair to say that they never really transcended the limited, formalist mode that offended liberal legalist sensibilities in the 1960s, nor for the most part did the judiciaries.

Again, as discussed above, judicial formalism in Taiwan and Korea should be understood in the context of political authoritarianism, in which assertions of power by the judiciary could be career ending, or perhaps worse. ${ }^{153}$ In such an environment, formalist reasoning probably feels like the safest course to the judge, as technically competent formalist reasoning will be convincing enough to get the job done in most cases, especially since the legal profession and legal academy share the formalist mindset. And in "hard" cases, where the law is obviously in doubt, or which involve obviously political concerns, formalism offers a refuge that the "modern" practices of openended policy analysis and the balancing of interests do not. In the Japanese context there is debate over whether politicians should be seen as the ultimate "principals" disciplining judges, or whether the judicial bureaucracy was essentially independent from the political side of government, with the top of the judiciary

152 Korea, for example, had only 811 lawyers in private practice in 1977. Kyong Whan Ahn, The Growth of the Bar and the Changes in the Lawyer's Role: Korea's Dilemma, in LAW AND TeCHNOLOGY IN THE PaCIFIC COMMUNITY 119 (Philip S.C. Lewis, ed. 1994) [hereinafter LAW AND TECHNOLOGY].

153 In the early 1970s, Seoul National University law professor Tsche Chongkil, who had recently returned from a lengthy stay at Harvard, was murdered by Korea's Central Intelligence Agency. Panel Recognizes Professor Killed in 1973 as Democracy Martyr, KOREA HeRALD, May 28, 2002. 
disciplining lower judges based upon its own criteria.154 Perhaps contributing to the continued formalism in Northeast Asia's legal professions and judiciaries was the fact that legal education in Northeast Asia remained highly formalist, centered on learning the provisions of the fundamental statutes, and their interrelations with one another. Yet all this "backwardness" coincided with not only with rapid economic growth, but also with dramatic improvements in broader "modernization" indices such as rising education levels and improving life expectancies.

Having satisfied ourselves that Northeast Asia got the best of the liberal legality and modernization theory, we should now ask ourselves why Northeast Asian societies now seem bent on finally establishing long absent pillars of the "modern" legal systems many foreign observers were not sure they needed. Beginning around 1990, the countries of Northeast Asia have entered into a multi-pronged effort at legal reform that seems driven by something very much like the modernization ethos. Starting, where else, with legal education, Japan, South Korea and Taiwan are all in the process of introducing "American-style" law schools. ${ }^{155}$ Japan has gone the furthest to date, licensing over seventy graduate-level "law schools," nearly all of which are located at universities which also have existing undergraduate and graduate law faculties.156 South Korea is currently planning to open graduate level law schools at eight to ten universities by 2008,157 and Taiwan is actively studying the situation. 158 Though the actual motives of the many parties involved in these processes will obviously vary, a central stated purpose of these initiatives is to improve legal education by getting away from the abstract, doctrinal teaching that has characterized undergraduate legal

154 See Upham, supra note 149 (presenting the contending positions).

155 A special issue of the Wisconsin International Law Journal contains papers on legal education reform in Taiwan, Korea, and Japan. 24 WIS. INT'L L. J. 1 (2006).

156 Sixty-eight law schools were licensed to open in April 2004, and four more were licensed to open in April 2005.

157 See Dong-yoon Chung, Law School Reforms Deserve Due Diligence, KOREA Herald, Jan. 5, 2007; Chung Ah-young, American-Style Law School to Debut in 2008, KOREA TIMES, Apr. 22, 2005; Hae-in Shin, American-style Law School Plan Causes Controversy, KOREA HERALD, May 19, 2005.

158 See Chang-fa Lo, Possible Reform for Legal Education in Taiwan: A Refined "J.D. System"?, 1 ASIAN J. COMP. L. issue 1, art. 7 (2006), http://www.bepress .com/asjcl/vol1/iss1/art7 (discussing Taiwan's possible adoption of the American J.D. system). 
education in the region, as in the civil law world generally (according to the American view). For example, to become more practically oriented, the new schools in Japan are experimenting with clinical legal education and inviting practitioners and judges to teach. ${ }^{159}$ This more practical education is supposed to turn out lawyers closer to the pragmatic problem-solvers of the modernization model. Getting students to pay attention to this new, practical curriculum requires changing the national bar exams, which have focused heavily on mastery of doctrine, much of it learned from cram schools and extra-university study. 160 Japan is therefore changing its bar examination, ${ }^{161}$ while Koreans are also discussing an "American style" bar exam to accompany the "American style" law schools. ${ }^{162}$

Coming in tandem with the creation of the new schools are moves to raising passing rates on national bar exams, so that the graduates of these new schools should enjoy a much greater chance of actually joining the bar than undergraduate law majors previously had. 163 While in the case of Korea it might be possible to achieve high passage rates for new law school graduates without increasing the total admitted to the bar per year by limiting the number of new schools and students, ${ }^{164}$ the Judicial Reform Commission's proposal along these lines was immediately criticized for abandoning real reform in the face of protectionist

159 See Lawrence Repeta, Omiya Law School and the "All Day Clinic," 25 Waseda Bull. Comp. L. 39 (2006); Peter A. Joy et al., Building Clinical Legal Education Programs in a Country Without a Tradition of Graduate Professional Legal Education: Japan Educational Reform as a Case Study, 13 CLINICAL L. REV. 417 (2006) (discussing the use of clinical programs in Japan's law schools).

160 For a penetrating discussion of the relationship between Korean legal education and the Korean bar exam, see JAMES M. WEST, EDUCATION OF THE LEGAL PROFESSION IN KOREA (1991).

161 Hisashi Aizawa, Japanese Legal Education in Transition, 24 WIS. INT'L L. J. 131, 147-50 (2006) (discussing Japan's new bar examination).

162 Shin, supra note 157.

163 It is actually misleading to talk about passing rates for bar exams as they have functioned in Northeast Asia. What they had were in fact numerical quotas, rather than passing rates.

164 Korea, which licenses approximately 1,200 new lawyers per year, is reportedly aiming for an $80 \%$ passage rate for graduates of the new law schools, but is contemplating in the range of 150 students at each of the 8 to 10 schools, Shin, supra note 157 , in which case no dramatic increase in the total number passing the exam should be necessary. 
pressures from the legal establishment. ${ }^{165}$ Although it may take some time, it seems clear that increasing the total numbers passing the bar will have to be part of the overall reforms. An increase in the size of the Japanese bar is much more certain. Having already allowed over seventy new graduate law schools to open, Japan will not be able to reach the high passage rates that were originally part of its new law school plan unless the annual quota is increased substantially. Given the high opportunity costs for many new law school students as compared with undergraduate law students, low passage rates would upset a lot of people.

With more lawyers, the story goes, societies will become more law governed, and more oriented towards the assertion of rights via litigation; in a word, more "rule of law."166 Reforming legal education should also get at the "problem" of judicial formalism, at least in the long term, though to expedite the process Japan and Korea are also planning to introduce lay participation in some areas of adjudication, interjecting potentially counter-formalist forces into the process. 167

All these new, practically oriented lawyers need something to do, and rather than wait to see whether they can create demand for their own services, governments in the region have simultaneously been engaged in a series of law reforms that depend upon increased private litigation. Specifically, all three countries have, over the past ten to fifteen years, amended their corporate and administrative law regimes to encourage, respectively, litigation by corporate shareholders against management, and by private

165 Editorial, Bigger Quotas Needed at New "Law Schools," HANKYOREH SHINMUN, April 23, 2005.

166 See Katsumi Yoshida, Legal Education Reforms in Japan: Background, Rationale, and the Goals to Be Achieved, 24 WIS. INT'L L. J. 209, 214 (2006) ("The ideal reform, as expressed in the report [of the Japanese Justice System Reform Council], was the realization of the rule of law, meaning that law with core values of liberty and fairness should permeate the state and society in Japan, taking root in the lives of ordinary Japanese people.").

167 Using the term "jury" is potentially misleading given differences between these proposed institutions and the Anglo-American ideal type. Nor are they modeled exactly on Germany's "lay assessors," however, so using the English translation of the civil law's main example of lay participation would also be misleading. On Korea, see Jong-moon Kim, Reform Panel Sees Juries in Place by 2007, JOONGANG DAILY, 1, col. 6, May 17, 2005; Chi-hyoung Cho, Judicial Reform: Proposed Civil Participation in Criminal Justice Process, Korea HeRALD, May 31, 2005. On Japan, see Kent Anderson \& Mark Nolan, Lay Participation in the Japanese Justice System, 37 VAND. J. TRANSNAT'L L. 935 (2004). 
parties against government agencies. ${ }^{168}$ Like other civilian legal systems, 169 those of Northeast Asia have not relied heavily on such "private" enforcement to achieve systemic goals such as constraining corporate management or government agencies. In keeping with the current trend, however, shareholder litigation is being actively encouraged by various technical fixes to procedural rules and corporate statutes, 170 as well as the enactment of shareholder class action statutes or other shareholder-centered systems using litigation to constrain management. ${ }^{171}$ Administrative litigation is being encouraged by the enactment of general administrative procedure statutes, which include some citizen participation in rulemaking, information disclosure laws, amendments to "administrative litigation" statutes, and the creation of dedicated administrative courts or benches. ${ }^{172}$ In doing so, they are opting to move towards the very "modern" idea of enlisting private interest, channeled through private litigation, in the public task of regulating corporate and government bureaucracies.

168 For more specifics on these reforms, see John K.M. Ohnesorge, Politics, Ideology, and Legal System Reform (forthcoming) [hereinafter Ohnesorge, Politics]. On administrative law reforms, see John K.M. Ohnesorge, Western Administrative Law in Northeast Asia: A Comparativist's History (2002) (unpublished S.J.D. dissertation, Harvard Law School) (on file with University of Pennsylvania Journal of International Economic Law); Tom Ginsburg, Dismantling the 'Developmental State'? Administrative Procedure Reform in Japan and Korea, 49 AM. J. COMP. L. 585 (2001).

169 See Guido Ferrarini \& Paolo Giudici, Financial Scandals and the Role of Private Enforcement: The Parmalat Case (Eur. Corp. Governance Inst., Working Paper No. 40/2005, 2005) (analyzing the effects of Parmalat on both sides of the Atlantic).

170 See Ohnesorge, Politics, supra note 168; Joongi Kim, Recent Amendments to the Korean Commercial Code and Their Effects on International Competition, 21 U. PA. J. INT'L ECON. L. 273 (2000) (discussing changes in Korean law which enhance shareholder's rights and ability to litigate).

171 See Joongi Kim, The Next Stage of Reforms: Korean Corporate Governance in the Post-Asian Financial Crisis Era, 1 ASIAN J. COMP. L., issue 1, art. 15, at 19 (2006), http://www.bepress.com/asjcl/vol1/iss1/art15; Curtis J. Milhaupt, Nonprofit Organizations as Investor Protection: Economic Theory and Evidence from East Asia, 29 YALE J. INT'L L. 169, 185 (2004); Dae Hwan Chung, Introduction to South Korea's New Securities-Related Class Action, 30 J. CoRP. L. 165, 168 (2004) ("One of the reform measures the [Korean] government has implemented is a class-action lawsuit system for use against securities-related firms.").

172 See John Ohnesorge, Chinese Administrative Law in the Northeast Asian Mirror, 16 TRANSNAT'L L. \& CONTEMP. Probs. 103 (2006); Ohnesorge, Politics, supra note 168; Ginsburg, supra note 168, at 586 ("Japan and Korea passed Administrative Procedure Laws for the first time in 1993 and 1996 respectively."). 
In doing so, moreover, these societies are moving in a direction that may have represented the consensus view of legal modernity circa 1970, but which, in the United States at least, has become very much contested terrain. Shareholder litigation as actually practiced in the United States is under constant attack from academics, ${ }^{173}$ politicians, ${ }^{174}$ and even newspaper columnists, ${ }^{175}$ as is the "adversarial legalism" of America's regulatory culture, ${ }^{176}$ and the idea of administrative law plaintiffs functioning as "private attorneys general."177 While it might be possible to develop interest group explanations for all these reform initiatives, to attribute shareholder litigation reforms to local plaintiffs bars or institutional investors, for example, it is hard to avoid the sense of a modernization ethos at work, with an idealized version of the U.S. system again providing the model. Shareholder litigation is considered a much more central part of corporate governance in

173 See, e.g., Roberta Romano, The Shareholder Suit: Litigation without Foundation?, 7 J.L. ECON. \& ORG. 55, 55-56 (1991) ("Critics of the shareholder suit assert that most of the suits are frivolous and that the plaintiff's bar is the true beneficiary of the litigation....").

174 During the 1990s Congress enacted two statutes to constrain shareholder litigation, the Private Securities Litigation Reform Act, Pub. L. No. 104-67, 109 Stat. 737 (1995) (codified as amended in scattered sections of 15 U.S.C.), and the Securities Litigation Uniform Standards Act, Pub. L. No. 105-353, 112 Stat. 3227 (1998) (codified as amended in scattered sections of 15 U.S.C.).

175 See George F. Will, Bull Market in Innuendo, WASH. PosT, June 12, 2005, at B9 (defending President Bush's nomination of Representative Christopher Cox to chair the Securities and Exchange Commission). For an overview of the movement to constrain shareholder litigation, see Michael A. Collora \& David M. Osborne, Class-Action Reforms Spur Derivative Claims, NAT'L L. J., Feb. 15, 1999, at B8.

176 See RoBert A. KAgAN, ADVERSARIal LEGALISM: THE AMERICAN WAY OF LAW (2001) (explaining criticisms of adversarial legalism); JERRY L. MASHAW \& DAVID L. HARFST, THE STRUGGLE FOR AUTO SAFETY (1990) (providing examples of failures of adversarial legalism).

177 In the federal courts, the battle has played out in the domain of standing doctrine, with critics of the private attorney general model, led by Justice Scalia, seeking to limit the ability of Congress to expand standing via "citizen suit" provisions. Friends of the Earth, Inc. v. Laidlaw Environmental Services (TOC), Inc., 528 U.S. 167 (2000), was a clear defeat for Scalia, but he and his allies have been fighting this battle since the 1980s, and there is no reason to think they will give up now, especially since Bush appointees Chief Justice Roberts and Justice Alito have joined the Court. For an overview, see William W. Buzbee, The Story of Laidlaw, Standing and Citizen Enforcement (Law \& Legal Theory Research Paper Series, Research Paper No. 05-13, 2005), available at http://papers.ssrn.com/ abstract $=721643$. For a resounding defense of the idea, see James R. May, Now More Than Ever: Trends in Environmental Citizen Suites at 30, 10 WIDENER L. REv. 1 (2003). 
the United States than in other influential corporate governance regimes, ${ }^{178}$ and with respect to administrative law, reforms such as information disclosure laws and rights of public participation in administrative rule making clearly have U.S. roots. But if we actually look at how shareholder and administrative litigation function in the United States, which as Trubek and Galanter pointed out long ago is exactly the kind of inquiry the modernization ethos biases us against,,${ }^{179}$ we might ask whether the "modern" U.S. system has resulted in better performance by either corporate management or by administrative agencies than that achieved in Northeast Asia. American corporate management may be more sensitive to short-term shareholder interests as a result of our active shareholder litigation culture, but that may come at the expense of longer-term outlooks that might benefit shareholders over the longer term, may make management too risk-averse, and perversely, might also pressure management to try to cover up negative financial results, resulting in real fraud. Our administrative litigation culture, by the same token, is hard to translate into better performance in specific regulatory fields, environmental and workplace safety regulation being primary examples, or into public legitimacy for the regulatory state.

What this all suggests is a different possible validation of modernization thinking, based on the idea that there is a logic of convergence that drives national legal systems towards a common set of characteristics. ${ }^{180}$ But this is not a simple economic logic, like some contemporary convergence arguments, because it is clearly driven only in part by economic forces. Rather, the logic of this convergence seems to be more cultural, in the sense of being driven by the spread around the globe of a set of common ideals with respect to the performance of national legal systems. ${ }^{181}$ While this mechanism is much more contingent and diffuse than the elite-led transition from traditional to modern in modernization thinking,

178 See Ferrarini \& Giudici, supra note 169 (arguing that private litigation is a more important part of enforcement of corporate law in the United States than Italy).

179 See Trubek \& Galanter, supra note 38, at 1081-82.

180 On convergence assumptions in modernization theory, see Ian Weinberg, The Problem of Convergence of Industrial Societies: A Critical Look at the State of a Theory, 11 COMP. STUD. SOC'Y \& HIST. 1 (1969).

181 See LaWrence M. Friedman, The Republic of Choice: LaW, Authority, AND CULTURE 201-02 (1990) (positing that legal systems in Western or developed countries are all being driven by a similar logic). 
this may make it all the more irresistible. The reason this trend matters for law and development is that it is in full force at the time when Northeast Asian governments are themselves becoming active purveyors of legal development assistance. ${ }^{182}$ One might have hoped that as Northeast Asian governments entered the law and development business themselves they would base their advice on realistic appraisals of how various areas of law functioned when they were developing countries. This seems not to be the case however, as the law and development efforts of Japan and Korea do not appear to offer much more nuance than the current international mainstream, and do not seem to be based on realistic self-assessment. ${ }^{183}$ Korea, for example, has joined the effort to convince developing countries of the great benefits of active competition policy despite the fact that Korea did not even have a competition law on the books until 1980, after roughly twenty years of high-speed growth. ${ }^{184}$

If modernization theory does not hold up well when confronted with the Northeast Asian experience, however, its chief antagonists, the dependency and world systems approaches, do not fare all that much better. Despite the fact that dependency and world systems thinking produced no orthodoxy oriented toward domestic law reform, for the same reasons that it is instructive to test law and development orthodoxies against Northeast Asian realities, it is also instructive to line up the broader economic and political claims of dependency and world systems theory against the Northeast Asian record. At one level, the Northeast Asian experience can serve as Exhibit $\mathrm{A}$ for those seeking to demonstrate the fallacies of these approaches. 185 As a descriptive matter, Northeast Asian states, beginning with Japan in the late nineteenth

182 See Ginsburg, supra note 172 (discussing law and development initiatives of Japan and Korea).

183 See Taylor, supra note 6 (analyzing various aspects of law and development projects in Japan).

184 See Joseph Seon Hur, Dir. Gen., Korea Fair Trade Commission, Capacity Building and Technical Assistance in the Area of Competition Policy: Korea's Experiences and Suggestions, Presentation to the OECD Global Forum on Competition (Feb. 14, 2002) (transcript available at http://ftc.go.kr/ data/hwp/20020214.doc) ("Korea adopted competition law in 1980 ...").

185 See, e.g., Richard E. Barrett \& Martin King Whyte, Dependency Theory and Taiwan: Analysis of a Deviant Case, 87 AM. J. SoC. 1064 (1982) (analyzing conflicting features of Taiwan's economy); Alice H. Amsden, Taiwan's Economic History: A Case of Etatisme and a Challenge to Dependency Theory, 5 MOD. CHINA 341 (1979) (arguing that the economic history of Taiwan contradicts dependency theory). 
century and followed by Taiwan and Korea after 1950, were not consigned by the world capitalist system to permanent membership in the periphery. Rather, while the world capitalist system was in full force, all three moved from the periphery to either the core (Japan), or close to it (Korea, Taiwan). This suggests that even if the categories of periphery, semi-periphery, and core capture basic descriptive truths about the world, to deny that their borders are permeable, at least under some conditions, is overly deterministic. In addition, if the developmental state theorists are correct, then dependency theory's specific distrust of the Third World state, one of its critiques of the modernization school, must be tempered. Furthermore, Northeast Asia's climb up the world systems hierarchy did not merely coincide with a global economy; rather there is near universal agreement that engaging in world markets was crucial to their achievements. Thus, if a prescriptive aspect of dependency and world systems approaches is that the global capitalist order produces the categories of the world system and that countries should therefore "de-link" from the international system in some systematic way, 186 the Northeast Asian experience can again provide a counter story. In fact, while one would have to search long and hard to find a country that has moved up the hierarchy by religiously following a free-market, free-trade orthodoxy, it would be equally hard to find lasting success among countries that have taken the "de-linking" advice of the dependency school very seriously. In any case, however, in our post-WTO, globalizing world "de-linking" hardly seems possible or normatively attractive to developing country policy makers, whereas the countries of Northeast Asia, which have made arguably the greatest advances within the world systems framework, have in fact been tightly integrated into the international trading system. ${ }^{187}$

If one looks a bit deeper, however, one finds substantial points of connection between dependency theory and the Northeast Asian experience. First, it seems clear that to many Northeast Asians the

186 For a de-linking argument, see SAMIR AMIN, DELINKING: TOWARDS A POLYCENTRIC WORLD (Michael Wolfers trans., 1990) (1985).

187 International financial markets are a different story, however. See Russell Mardon, The State and the Effective Control of Foreign Capital: The Case of South Korea, 43 WORLD POL. 111 (1990) (discussing the integration of foreign capital into Korean industry); Robert Wade, East Asian Financial Systems as a Challenge to Economics: Lessons from Taiwan, CAL. MGMT REV., Summer 1985, at 106 (discussing Taiwanese financial markets). 
picture of the world presented by dependency and world systems theorists seemed largely accurate. The world actually is divided between the "haves," who command the industrial, technological, financial and military heights, and the "have nots." Furthermore, as inheritors of proud cultures and histories, many Northeast Asians seem to have shared with dependency theorists the notion that they were among the "have nots" largely as a result of imperialism, although perhaps combined with some poor decisions on their own part. Although this mindset sees the possibility of movement up on the world systems ladder, it rejects the idea of de-linking, and in fact sees the possibility of progress only in aggressive engagement with the global economy; to many observers it is essentially mercantilist rather than liberal. The global economic order is treated with caution, and while widespread import substitution was of limited duration in Northeast Asia, a concern for self-reliance was reflected in the creation of elaborate mechanisms to channel and moderate connections with the international economy. ${ }^{188}$ While Northeast Asian governments behaved as if the levels of the international economic order were upwardly permeable, they also behaved as if they were downwardly permeable, if international economic forces were left unmediated. Northeast Asian economic development may present a "challenge to dependency theory," to use economist Alice Amsden's phrase from an early essay on Taiwan, ${ }^{189}$ but that challenge is based on a different set of solutions more than on a different diagnosis of the essential problem facing poor countries. For this reason, scholars of Northeast Asian economic thought have long explored the influence of Friedrich List, the nineteenth century German theorist, on Northeast Asian economic thinking. ${ }^{190}$ List's nationalist prescriptions for late-industrializing Germany, and his critique of the cosmopolitan free-trade advocated by Adam

188 Appeals to self-reliance are of course used to justify simple interest-group protectionism, but particularly in the case of South Korea, the drive for national technological competence seems clearly in part based on national concerns for self-reliance.

189 See Amsden, supra note 185, at 341-79.

190 See Richard J. Samuels, Rich Nation, Strong ARmY: National Security AND THE TECHNOLOGICAL TRANSFORMATION OF JAPAN 5-8 (1994) (detailing Japan's changes in technology); Ohnesorge, supra note 35, at 315-16 (discussing Freidrich List's influence); Kenneth B. Pyle, Advantages of Followership: German Economics and Japanese Bureaucrats, 1890-1925, 1 J. Japanese Stud. 127 (1974) (discussing the influence of List's writings on East Asia). 
Smith, bear a much closer resemblance to Northeast Asian trade practices than do the prescriptions of dependency theory. ${ }^{191}$

\subsection{Northeast Asia and the Neoliberal Rule of Law}

Leaving aside the matter of rule of law rhetoric masking power politics, and the question of whether the mistakes of the modernization era were being repeated, how do the claims of the neoliberal rule of law orthodoxy fare when compared with the Northeast Asian experience? Not very well, it turns out, at least not in strong form. First, on the level of private law and private property rights, the Northeast Asian experience provides good reason to think that constitutional law protecting property rights is not crucial to the overall development picture. Despite the fact that development was basically privately lead, the dictators who oversaw development in Korea and Taiwan were unconstrained by constitutional law in any direct sense, showing it not to be necessary even to the relatively equitable economic growth that should please progressives. Clearly a political commitment to capitalism is enough, both for local entrepreneurs and for foreign investors, as China is demonstrating once again.

Furthermore, as we know from the United States' experience, even a very firmly established system of constitutional review is not really sufficient to protect private property, if protection means insulation from regulation or compensated takings, as well as from uncompensated takings. Property rights absolutism in the United States is a political agenda that is simply not reflected in constitutional law, as the Supreme Court's "regulatory takings" jurisprudence and recent eminent domain decision show. ${ }^{192}$ The Court has proven to be unwilling to expand the regulatory takings doctrine to protect property rights from anything but the most extreme economic destruction via regulation, 193 but has never provided property owners with clear guidance as to what is the actual scope of the doctrine. ${ }^{194}$ Likewise, in Kelo the majority of the Court extended its century-long generous interpretation of "public

191 See Friedrich List, THE NATIONAL SYSTEM OF POLITICAL ECONOMY (Sampson S. Lloyd trans., 1885) (1977) (reveling List's economic theories).

192 Kelo v. City of New London, 545 U.S. 469 (2005).

193 See NEIL K. KOMESAR, LAW'S LimITS: THE RULE OF LAW AND THE SUPPLY AND DEMAND OF RIGHTS 88-112 (2001) (providing example of court being unwilling to expand the regulatory takings doctrine).

194 See id. (providing example of vagueness of doctrine). 
use" under the Fifth Amendment, which essentially facilitated the taking of property by government via eminent domain. It also highlighted the extent to which the narrow position advocated by the plaintiffs, and accepted by the dissenters, has its basis more in political ideology than in American economic history.

This is not to suggest that property rights in the United States are an illusion, or that developing countries should not have constitutional law and judicial review to protect them. But whether a country is a dictatorship, like Korea and Taiwan were in their high-growth eras, or a democracy, like the United States and post-WWII Japan, the idea that law and development activities can lead to the locking in of "rules of the game" protecting private property from the state is fanciful, and perhaps downright dangerous. Because so much neoliberal rule of law theorizing seems to have been driven by the problems of 1990 s Russia, 195 it is useful to consider subsequent events there. It is unclear how far President Putin will go in reasserting the powers of the Russian State to undo the "reform" privatizations of the early 1990s, which Russian analyst Anatol Lieven calls "the single greatest example of such plundering in the whole of modern history," which "crippled the ability of the Russian state to provide basic services to its population-including for long periods even wages and pensions." 196 But Putin's rise is clearly a reaction to the neo-liberal excesses of that period, ${ }^{197}$ and we (and, most importantly, the Russians) will now just be very lucky if his counterrevolution stops short of real authoritarianism.

The story with administrative law is much the same, with even democratic Japan contradicting the orthodoxy in important ways. All three countries maintained extensive regulatory screening systems to modulate cross border flows of technology and capital, and the bureaucracies responsible for these screens had a great deal of discretion to operate them free from the fear of judicial

195 See, e.g., WORLD BANK, supra note 105; Gray, supra note 87 (presenting an overview of how the collapse of command-and-control economies in the former Soviet Union has given particular impetus to new worries and questions about the state's role).

196 Anatol Lieven, Is Khodorkovsky Really the Victim?, INT'L HERALD TRIB., June 10,2005 , at 7.

197 See id. (suggesting that Putin's authoritarianism was somewhat understandable in light of the Oligarchs' exploitation of the laissez-faire atmosphere immediately following the demise of the Soviet Union). 
challenge. ${ }^{198}$ In the words of an American lawyer practicing in Japan in the early 1960s,

[I]t might be well to state explicitly that the "rule of law," insofar as it is intended to connote judicial review of economic determinations of governmental agencies, is virtually nonexistent in Japan. [With respect to foreign exchange and foreign investment control laws] the criteria for administrative decision are nothing but restatements of the broadest policy considerations. Beyond this there is nothing, and an appeal for judicial review of a decision of the Ministry of International Trade and Industry to allow, say, a twenty-five per cent foreign equity holding in a joint venture corporation instead of a forty-nine percent holding, or a Ministry of Finance determination to allow only a five per cent rate of interest on a validated loan from abroad instead of an eight per cent rate, would be unprecedented; the mere suggestion of it, in fact, sounds fatuous. ${ }^{199}$

These screening mechanisms the Northeast Asian governments erected between their economies and the international economy drove the industrial policy debate of the 1980s as well as the developmental state tradition in economics and political science, and it is no coincidence that "administrative guidance," the tendency of Northeast Asian administrators to rely on unwritten suggestions instead of formal dispositions, became the aspect of Northeast Asian administrative law that really interested the West. But on purely domestic matters, as well, there is broad agreement among observers that government-business relations were comparatively unstructured by formal administrative law. So even

198 See F.L. Hartman, Japanese Foreign Investment Regulation: Semantics and Reality, 18 N.Y. L.F. 355, 355 (1972) (explaining that in Japan, "businessmen and government officials maintain that local companies continue to need paternal governmental protection from foreign competition and foreign capital."); KungChung Liu, Legal Environment for Technology Transfer in Taizan, 36 INT'L LAW. 1145, 1154 (2002) (discussing the debate within Taiwan as to "whether to give IP right holders the exclusive right to import goods produced with their permission ... ."); Russell Mardon, The State and the Effective Control of Foreign Capital: The Case of South Korea, 43 WORLD POL. 111, 113 (1990) (examining the governmental strategies that allowed South Korea to benefit from foreign inflows of capital while preventing foreign control of businesses and the markets).

199 Carl J. Bradshaw, Selected Legal Aspects of Business in Japan, 14 STAN. L. REv. 639, 680-81 (1962). 
if the Hayekian picture state-society relations put forth in the neoliberal rule of law orthodoxy is problematic with respect to the United States, which it certainly is, it even less accurately describes the role of administrative law in structuring state-society relations during the Northeast Asian miracle. This seems clear, moreover, whether one accepts the "developmental state" claim that it was the state that maintained the upper hand in state-society relations, or whether one believes with either the traditional left, or with rational choice observers, that the state essentially served certain private interests. From either angle the relationships did not fit the rule of law orthodoxy.

As for the alleged centrality of modern property and contract law to the functioning of the market, Japan and Taiwan, and arguably to a lesser degree Korea, all had highly evolved commercial traditions prior to the importation of Western legal rules and institutions, which were imported en masse in the late nineteenth and early twentieth centuries, more or less simultaneously with the importation of Western communications, transportation, manufacturing, and organizational technologies. To borrow from the lingo of modernization theory, there occurred a "Big Push" in importing Western governance as well as mechanical technologies, and under those circumstances attempts to isolate and evaluate the contribution to development of some particular legal institution are going to be extremely difficult. Moreover, two of the oldest stories on the Asian law shelf concern the lack of formality in private contracting relations-short contracts, relationships matter more than form anyway, etc. ${ }^{200}-$ and the low incidence of litigation. ${ }^{201}$ Informality in contracting is not so much a problem for law and development theory, as NIE includes social and cultural norms within the institutional matrix, and the literature contains numerous references to non-contractual relations, ${ }^{202}$ informal trading networks, ${ }^{203}$ and the importance of

200 See Veronica Taylor \& Michael Pryles, The Cultures of Dispute Resolution in Asia, in DISPUTE RESOLUTION IN ASIA 1, 1-2 (Michael Pryles ed., 1997) (providing specific details on Asian transactions and disputations). For evidence that this tradition persists, see Craig Parry, Do Business in Japan by Following the Way of 'Wa,' CORP. COUNS., Nov. 20, 2006 (suggesting that in Japan, the relationship of trust developed between two businessmen is more important than the specific terms of their eventual agreement).

201 See Lawrence M. Friedman, Law, Legal Institutions, and Economic Development, in LAW AND TECHNOLOGY, supra note 152, at 7 (exploring a few general ideas and theories about the relationship between law and society).

202 See, e.g., Simeon Djankov et al., Courts, Q. J. ECON., May 2003, at 453, 453 
alternative dispute resolution. ${ }^{204}$ The problem comes more at the level of practice, where calls to pay attention to all these non-legal realities, which might differ from country to country, ethnic group to ethnic group, or industry to industry, seem to give way to the perceived need for top-down reform. ${ }^{205}$ But if social norms really do matter, and if law is also potentially potent, as it must be for social engineering through law to make any sense as all, then it is not hard to imagine fouling up well-functioning markets with illconceived top-down law reforms.

Northeast Asia's low litigation rate presents more of a problem because the orthodoxy seemed to make strong claims for the necessity of competent, efficient, user-friendly courts to a successful market economy. ${ }^{206}$ This is not the image of Northeast Asia's courts that has prevailed among observers, however, where the practitioners have long bemoaned the situation, and the main academic discussion has been over whether low litigation rates were culturally or structurally driven. ${ }^{207}$ This was always a bit misleading, however, as Northeast Asian business people certainly took legal disputes to court, but the reality of that litigation is quite far removed from the rhetoric of the orthodoxy. The fact that Northeast Asians have now decided to encourage litigiousness, discussed above, does not change the reality of the earlier era.

(citing ROBERT ELLICKSON, ORDER WITHOUT LAW: HOW NEIGHBORS SETTLE DisPUTES (1991); Stewart Macaulay, Non-Contractual Relationships in Business: A Preliminary Study, 28 AM. SOC. REV. 55 (1963)).

203 See, e.g., Richard E. Messick, Judicial Reform and Economic Development: A Survey of the Issues, 14 WORLD BANK RES. OBSERVER 117 (1999) (citing Avner Greif, Contracting, Enforcement, and Efficiency: Economics Beyond the Law, in ANNUAL WORLD BANK CONFERENCE ON DEVELOPMENT ECONOMICS 1996239 (Michael Bruno \& Boris Pleskovic eds., 1996)).

204 See, e.g., WORLD BANK, supra note 99, at 93 (describing the important role that alternative dispute resolution mechanisms have played in Russia and East Asia).

205 See, for example, the unenthusiastic response of World Bank economist Cheryl Gray to Robert Cooter's call for law reforms to be based upon existing social practices. Cheryl W. Gray, Comment on Robert D. Cooter, "The Rule of State Law and the Rule-of-Law State: Economic Analysis of the Legal Foundations of Development," in WORLD BANK ANNUAL CONFERENCE ON DEVELOPMENT ECONOMICS 1996 , at 218.

206 WORLD DEVELOPMENT REPORT 1996, supra note 99, at 93-94.

207 See Tom Ginsburg \& Glenn Hoetker, The Unreluctant Litigant? An Empirical Analysis of Japan's Turn to Litigation, 35 J. LEGAL STUD. 31 (2006) (adding an empirical analysis to the academic debate on structural versus cultural barriers to litigation). 
Finally, if one examines the specific legal fields that loom large in the orthodoxy, areas such as insolvency law, competition law, and corporate law, it is not hard to show that the roles claimed for them in the orthodoxy do not match the roles they played in Northeast Asian economic development. The most glaring example is intellectual property law, which in Northeast Asia has failed, and continues to fail, to live up to the demands that mainstream law and development literature would place on developing countries. Korea and Taiwan are still perpetual offenders under United States trade laws designed to pursue foreign governments that do not effectively protect United States intellectual property rights. ${ }^{208}$ At the very least this shows that protection of foreign intellectual property plays an uncertain role in economic development, and depending upon whether domestic IP holders used the legal system to protect their interests during the high growth era, it may be that even the importance of IP law for domestic purposes should be reexamined. Formal insolvency regimes were relatively little used, ${ }^{209}$ and competition law was notoriously unsuccessful as a tool for combating cartels. ${ }^{210}$ Although Japan's Fair Trade Commission is now undertaking a high-profile attack on a bid-rigging cartel among specialized bridge building firms, 211 this cartel existed for over forty years, and was so little concerned with the law that it published and distributed rule books to relevant employees from member companies. Japan may now be using the law more aggressively to enforce competition, but it has been a long time coming. ${ }^{212}$ And

208 U.S. TRADE REPRESENTATIVE, 2005 SPECIAL 301 REPORT 42 (2005) (describing the steps taken by Korea over the past year to significantly strengthen its intellectual property regime).

209 Terence Halliday \& Bruce Carrothers, Epistemological Conflicts and Institutional Impediments: The Rocky Road to Corporate Bankruptcy Reforms in Korea (Am. B. Found., Working Paper No. 2211, 2003).

210 See John O. Haley, Competition Policy for East Asia, 3 WASH. U. GLOBAL STUD. L. REV. 277, 278 (2004) (arguing that competition law can only be effective when the state is not itself imposing structural barriers to competition); Kozo Yamamura, The Development of Anti-Monopoly Policy in Japan: The Erosion of Japanese Anti-Monopoly Policy, 1947-1967, in 2 STUD. IN L. \& ECON. DEV. 1, 22 (1967) ("[T]he present Japanese pro-monopoly policy has successfully emasculated all but a few remnants of . . . anti-monopoly legislation as it existed after World War II.").

211 Kazuhiko Takeshima, Chairman, Japan Fair Trade Comm'n, Remarks for the Session on "Cartels and Other Anti-Competitive Agreements" (Nov. 4, 2006).

212 Japan's Fair Trade Commission can take a comparatively aggressive stance when it wants to, as it has in taking action against Intel for "exclusionary 
while modern corporate law completely penetrated these economies in the sense that the important firms were organized and operated as corporations, or networks of corporations, the reality was far from the model. In Taiwan the most important corporations were either controlled by families or by the Partystate apparatus of the Kuomintang, while in Korea the important corporations were virtually all family or state controlled.213 Minority shareholder rights existed on paper, of course, but judicial enforcement of those rights did not play a serious role in corporate governance. ${ }^{214}$ Even in Japan, where corporate law mattered more to the reality of corporate governance, shareholders exercised control mainly through large, relatively stable holdings, not through threat of litigation, to enforce their legal rights. ${ }^{215}$

\subsection{Legal Origins and Northeast Asia's Development}

As noted above, although the neoliberal rule of law vision remains part of the picture, the center of gravity in the law and development world has shifted in the direction of two very different "proto"-orthodoxies, the legal origins and the comprehensive development approaches. As with the modernization and neoliberal rule of law orthodoxies, it is instructive to compare the claims of these approaches with the Northeast Asian experience. Turning to the legal origins approach first, the most obvious thing to say if one thinks about the Northeast Asian experience is that these were all fundamentally

pricing" policies that may not be actionable in the United States. See, e.g., Spencer Ante, AMD Hauls Intel Back to Court, BUS. WEEK ONLINE, June 28, 2005, http://www.businessweek.com/technology/content/jun2005/tc20050628_6337 _tc119.htm (describing the suit filed by Advanced Micro Devices on June 27 against chip giant Intel "for a series of alleged antitrust violations AMD says are aimed at crippling the smaller chipmaker").

213 See Claessens, supra note 32, at 3 ("We also find that smaller firms are more likely family-controlled, as are older firms.").

214 See Yin-Hua Yeh, Tsun-siou Lee \& Tracie Woidtke, Family Control and Corporate Governance: Evidence from Taiwan, 2 INT'L REV FIN. 21 (2001) (using a sample of Taiwanese firms to analyze the relationship between corporate governance and family control); Yin-Hua Yeh \& Tracie Woidtke, Commitment or Entrenchment?: Controlling Shareholders and Board Composition, 29 J. BANKING \& FIN. 1857, 1859 (2005) ("Taiwan represents an ideal setting to examine these issues because it features relatively weak protection of minority shareholders ...."); Kim, supra note 171, at 18 ("Weak public and private enforcement remains one of the biggest challenges in Korea as in much of Asia.").

215 See Milhaupt, supra note 171 (explaining shareholder enforcement schemes in East Asian countries). 
civilian legal regimes, whether in the formal attributes of the law, or in the organization and functioning of institutions such as the judiciary, the legal profession, or legal education. Whatever advantage can be proven for the common law through the use of statistical models, having a civilian legal system cannot be much of a handicap. But even though these were all basically civilian systems, they were also all hybrids to one degree or another with respect to corporate and securities law, which had been influenced by U.S. norms, so "coding" them for cross-country statistical comparison presents serious problems. ${ }^{216}$ In addition, however, the history of Northeast Asian law is replete with "legal transplant" failures, in which the imported rule or institution did not function as hoped. Coding these legal systems, or any other for that matter, therefore cannot be fixed by just paying attention to hybridization of the formal legal rules, but could only be plausible if supported by sustained research into actual legal system functioning, the law "in action."

Turning to more specific issues, Northeast Asian corporations have succeeded under very different models of corporate governance, and in none of these models did corporate law provide extensive protections for minority shareholder rights. The prototypical corporation in Taiwan and Korea was dominated by controlling shareholders, with no separation of ownership and control. These owners were in turn checked by a variety of forces, including the competition of product markets, the "exit" option enjoyed by shareholders, and interventionist governments controlling the banks from which they borrowed. Legal rights of minority shareholders were inconsequential. As is well known, the dominant pattern in Japan was different, with ownership and management separated, but with monitoring of management again provided largely through forces other than minority shareholder rights to sue management. Given the central role corporations have played in Northeast Asian economic development, it is hard to argue for the importance of minority shareholder rights on development grounds, unless one is already assuming the superiority of stylized Anglo-American capitalism, which of course faces its own Northeast Asia problem.

Other policy prescriptions one might draw from the legal organs literature fare a little better. The deep and liquid financial

216 See Spamann, supra note 125 (discussing coding problems in the legal origins literature). 
markets that the early law and finance studies associated with common law jurisdictions can be efficient allocators of capital, but bank-centered financial systems are clearly compatible with successful economic development. Likewise activist, interventionist governments, which this literature associates with the civil law tradition, can clearly go hand in hand with astounding economic development, even if they can also be prone to red-tape and rent-seeking, as the literature tries so hard to demonstrate. Finally, judicial independence, for which this literature seeks to provide an economic development rationale, hardly thrived during Northeast Asia's most rapid economic development. Like other elements of the legal origins policy package, the argument for judicial independence seems to rely on background assumptions about the superiority of a stylized AngloAmerican political economic tradition, assumptions which Northeast Asia's economic miracle should call into question.

It is telling that in its eight pages the References section of Doing Business 2004: Understanding Regulation ${ }^{217}$ contains not a single reference to scholarship on Northeast Asian economic development in any field, let alone scholarship on the role of law in Northeast Asian development, and only one piece authored (coauthored, actually) by a serious student of Northeast Asian law.218 Perhaps the bias this proto-orthodoxy displays against civilian jurisdictions is simply a failure in sample selection, but that seems unlikely given the technical sophistication of the scholarship and the stakes involved. Whether the selection bias was outcome driven, or due to some morbid tendency to study failure, it is glaring considering Northeast Asia's dramatic success.

\subsection{Comprehensive Development and Northeast Asia}

The comprehensive development approach has much to commend it, at least to those who share its underlying assumption that having a decent society involves more than just "getting the rights right," and the approach may help insulate law and development projects from criticism, at least from the left. But a clear-eyed look at Northeast Asia's experience suggests that the

217 WORLD BANK, DOING BUSINESS IN 2004: UNDERSTANDING REGULATION, supra note 128 , at 97 .

218 See Katharina Pistor et al., Innovation in Corporate Law, 31 J. COMP. ECON. 676 (2003) (suggesting that resilience of the corporate form is a function of the adaptability of the legal framework to a changing environment). 
approach is either wrong, or succeeds only through redefining development in a way that risks the ethno-centrism of the modernization approach. We have seen how Northeast Asian legal systems failed important aspects of the neoliberal rule of law orthodoxy, but comprehensive development fares even worse, though this is not surprising since in many ways it just represents an addition of additional items to the laundry list, rather than a fundamentally different approach. When we look at some of these additional items, their failures become equally clear.

Labor rights in Northeast Asia have long been criticized by local and foreign observers, ${ }^{219}$ for example, and the Korean case is particularly interesting for being criticized by both the left and the right. The left claimed, accurately, that the government cooperated with business in using illegal means to suppress independent unions, trying to instead coerce a system of company (not trade) unions, which would all belong to the docile, governmentapproved national peak union.220 Business groups, meanwhile, complained that Korean labor markets were insufficiently flexible because of the protections the law provided to individual workers. To give but one example, Korea, like Japan, 221 does not allow atwill termination, 222 a provision that particularly baffled American investors. Perhaps the simplest way to understand Korean labor regulation is as paternalist, meaning that it rejected a free-market model by including comparatively rigid protections for those worker interests that it recognized, but at the same time discouraged litigation to enforce these rights, and also discouraged labor from organizing in ways that would allow it to become a political force in its own right, participating in the definition of its

219 See, e.g., FREDERIC C. DEYo, BENEATH THE MIRAClE: LABOR SUbORdiNATION IN THE NEW ASIAN INDUSTRIALISM 66 (1989) ("[T]he available impressionistic evidence points to a trend toward increasingly unfavorable outcomes for labor.").

220 See James M. West, South Korea's Entry Into the International Labor Organization: Perspectives On Corporatist Labor Law During A Late Industrial Revolution, 23 STAN. J. INT'L L. 477, 525 (1987) (discussing other forms of state interference with labor autonomy).

221 See Ryuichi Yamakawa, Labor Law Reform in Japan: A Response to Recent Socio-Economic Changes, 49 AM. J. CoMP. L. 627, 645 (2001) ("One of the most distinctive features of Japanese labor law is the case law doctrine of abusive dismissal.").

222 See Jeong Han Lee, South Korea: Key Limits on Employer Latitude in Structuring Workforce, (Bae, Kim \& Lee PC, 2007), available at http://www.mondaq.com/article.asp?articleid=46866 (explaining the restrictions on termination in Korea). 
interests. ${ }^{223}$ It seems likely that replicating Japan's labor situation was the goal of this system, as after the 1950s Japan enjoyed relative labor peace, while also keeping labor's role in setting the terms of the overall political economy comparatively limited.224 Particularly in Korea and Taiwan,225 the state did not stop with merely legal means to enforce this regime, but also resorted to illegal measures to keep labor under control.

With respect to civil and political rights, social justice, sustainable development, access to justice, or the other add-ons that differentiate the Comprehensive Development approach from the neoliberal rule of law orthodoxy, Northeast Asia fared little better during its high-growth decades, and not everything has changed. In the spirit of Comprehensive Development, the World Economic Forum ("WEF")

has begun to explicitly incorporate in its measures of competitiveness aspects of gender equality, recognizing that, far from being a matter of mere political correctness, the advancement of women is an important strategic issue. Countries which do not capitalize in the full potential of one half of their societies are misallocating their human resources and compromising their competitive potential.226

While it is hard to disagree with the proposition that misallocating its resources makes a country less competitive, the fact that Korea ranked fifty-fourth out of fifty-eight countries in the WEF's 2005 gender equality study, while Japan came in at thirtyeighth, 227 suggests that the subjugation of women in Northeast

223 See West, supra note 220, at 522 (referencing criticisms of the South Korean government's overbroad invocations of the "public interest" to justify denials of the right to strike).

224 See T. J. Pempel \& Keiichi Tsunekawa, Corporatism Without Labor?: The Japanese Anomaly, in TRENDS TOWARD CORPORATIST INTERMEDIATION (Philippe C. Schmitter \& Gerhard Lehmbruch eds., 1979); DEYO, supra note 219, at 51-86 (discussing general trends in East Asian labor movements).

225 T.K., LETTERS FROM SOUTH KOREA (David L. Swain trans., 1976).

226 AUGUSTO LOPEZ-ClAROS \& SAADIA ZAHIDI, WORLD ECONOMIC FORUM, WOMEN'S EMPOWERMENT: MEASURING THE GLOBAL GENDER GAP 2 (2005), available at http://www.weforum.org/pdf/Global_Competitiveness_Reports/Reports/ gender_gap.pdf.

227 Id. at 9. The World Economic Forum excludes Taiwan in favor of China, so Taiwan was spared inclusion. Taiwan would probably do better than Japan or Korea, though there is no reason to think that has helped it out-compete the other two in any respect. 
Asia has not been a significant drag on their economies, though that is no reason not to treat it as a very serious human rights problem. One might argue, though this would be data dependent, that keeping women at home working without wages helped enable rapid development because governments did not need to provide decent social safety nets, though this would be not be compatible with the idea of equitable development. The World Economic Forum invoked the idea of "misallocating resources" in its argument for gender equality because it evokes the apolitical, technocratic authority of economics, but the claim is highly questionable. Women have obviously played enormously important roles in Northeast Asian economic development, but if we claim that those roles resulted in the "misallocation of resources" then it seems that what we have done is to turn resource allocation into a normative question, and then answered it by asserting our own values. That is not the answer to the problems of law and development.

The same argument applies to civil and political rights more generally, which were severely curtailed in Korea and Taiwan for decades, with martial law, restrictions on the press, restrictions on travel, and quasi-police state measures to penetrate all levels of society.228 Social safety nets were very thin by Western standards, 229 and to the extent that "sustainable" development means environmental protection and forcing manufacturers to internalize the costs of the pollution they produce, growth was put over sustainability. ${ }^{230}$ Nor was access to justice ever given much emphasis in Northeast Asia, as the formal legal system remained relatively distant from the lives of ordinary citizens. Legal professions were intentionally kept tiny compared to general populations, as were judiciaries, and while other law-related professions and non-judicial dispute settlement took up some of the unmet demand, nobody has ever argued that Northeast Asian

228 See John Kie-Chiang OH, Korea: Democracy on Trial (1968) (depicting the curtailing of rights in Korea); RoY, supra note 21, at 76-104 (describing Taiwan's one-party rule under the Kuomintang); T.K., supra note 225.

229 Robert Wade, in an early article on Northeast Asian financial systems, pointed out a possible function for thin social safety nets in Northeast Asia, which is that they probably boosted savings rates, feeding funds to the state-controlled banking system, which governments could then use to fund targeted industries. Wade, supra note 187, at 109.

230 See, e.g., NORMAN R. EDER, POISONED PROSPERITY: DEVElOPMENT, MODERNIZATION, AND THE ENVIRONMENT IN SOUTH KOREA (1995). 
citizenries were given easy access to their formal legal systems.

One can say, therefore, that if the claim is that economic development, as traditionally understood, requires the comprehensive development rule of law, then the claim is simply wrong. The record, in fact, better supports the older economy-first arguments that it is the suppression of individual rights and democracy that is somehow positively related to economic development, and that rights and democracy will come later. Whatever its other faults, that argument at least benefits from an obvious correlation in the Northeast Asia experience, where growth did come before democracy and social advances, whereas the "comprehensive development" approach is directly contradicted. It is clear, though, that development for advocates of the "comprehensive development rule of law," is not limited to economic development, but has been redefined to include a range of social aspects beyond economic growth. ${ }^{231}$ It may be that the rule of law, whatever that means, is now an end in itself, no longer a means to an end as it had been presented in the neoliberal rule of law vision. ${ }^{232}$ But then there is a circularity problem: if we define "development" to include right/value $X$, then a legal system that enshrines and effectively protects right/value $X$ is going to be a prerequisite to development. This move just brings us back to the "modernization" mindset, in which development lost any concrete grounding, and came to mean being the way we wished ourselves to be. This is problematic on several grounds, however, some of which have been raised already.

First of all, Northeast Asian societies, despite not conforming to any of the law and development orthodoxies, are highly successful societies in many respects. In fact, it often seems to be Northeast Asia's successes, whether in building cars, in life expectancy, or in education, raise international standards and thus push us to do better. Thus there is something deeply ethnocentric about any attempt to build a comprehensive ("modern") socio-legal model to be sold to today's developing countries that does not take Northeast Asia seriously. Furthermore, given that law and legal

231 See AmartYa Sen, Development As FreEdom 281 (1999) (“Public policy has a role not only in attempting to implement the priorities that emerge from social values and affirmations....").

232 Rittich, supra note 41, at 203 ("[Probing] the manner in which the IFIs are managing the incorporation of social justice and greater participation in the development agenda ...."). 
systems are intensely political, there are good reasons to be skeptical about ever-expanding definitions of their tasks by law and development practitioners, especially from the IFIs. Any law and development approach is going to be political, and law and development orthodoxies inevitably involve normative pictures of how their creators wish the world were. But limiting the objective to some measure of economic performance seems less imperialistic than an open-ended mandate to remake societies. And even though law and development practitioners can always fall back on the formal excuse that they are simply doing what's been requested by the local government, if a legal field is at all contested in a society, an invitation from the current regime will very likely just mean siding with the winner in very political local debates. ${ }^{233}$ This is not only playing in local politics in everything but the most formalist sense, but it also means that reforms pushed through in this way will very likely lack the true local ownership that would give them real stability.

\section{BEYOND CRITIQUE: NEW APPROACH TO LAW AND DEVELOPMENT FROM THE NORTHEAST ASIAN PRACTICE}

Despite Northeast Asia's unquestioned developmental success in the economic, social and political arenas, and the enormous body of research that success has spawned in other fields, none of the important law and development orthodoxies developed as of yet comes close to capturing the dynamics of law and development in the region. But this Article is not simply a critique. Part IV, below, suggests a new approach to law and development work, an approach informed by the ways in which the existing orthodoxies

233 The IMF and World Bank initiatives in Korea resulting from the Asian Financial Crisis certainly had this flavor, as the left-leaning government of President Kim, Dae-Jung used the opportunity to push through measures against the Korean chaebol that were opposed by conservatives. See, e.g., Kim, supra note 7, at 68-69 (describing the process by which Korea restructured its financial markets); WORLD BANK, REPORT NO. PID6726, KOREA - FINANCIAL AND CORPORATE Restructuring Assistance ProjeCt 1 (1998) ("With support by the IMF and World Bank adjustment lending, the authorities then stabilized the economic situation and encouraged the drastic restructuring of banks and corporations. In doing so, the Government that came to power in 2/98 seeks to also address some of the fundamental beliefs and behaviors that had contributed to the structural problems in the economy."); see also WORLD BANK, REPORT NO. 25214, IMPLEMENTATION COMPLETION REPORT ON A LOAN IN THE AMOUNT OF US\$48 Million to THE REPUBLIC OF KOREA FOR A FINANCIAL AND CORPORATE RestruCtURING Assist ANCE Project, (2003). 
have failed the Northeast Asia test.

\subsection{The Limits of Critique}

Criticism of law and development orthodoxies is important, both as a way to challenge existing approaches, and as an exercise that can encourage critical thinking about relationships between law, economics, politics and social life. But when new bursts of law and development activity come, it often seems as if criticism of the last round, if noted at all, has had limited impact. It seems clear, for example, that Trubek and Galanter's attack on the assumptions of the first law and development movement has had a more lasting effect on legal thought, through its contributions to the Critical Legal Studies and Law and Society movements, than it has on the law and development agenda as such. For anyone interested in affecting law and development practices it is important to consider why this might be.

One possibility might be simple political ideology, and some criticisms seem based on the idea that the staff of places like the World Bank or the IMF is the problem.234 There is certainly some truth to that, for it is clear that currents in the economic academy affect thinking about development, which affects law and development activities. ${ }^{235}$ But the World Bank at least appears to be staffed more with moderate, internationalist liberals than with ideologues,236 so one would expect them to be sympathetic to reasoned arguments that their approach to law and development is not working. 237 Great Power politics also clearly matters, so the goals of the United States in particular are going to be reflected to some extent in law and development activities by the IFIs. ${ }^{238}$ But

234 See, e.g., JOSEPH E. STIGLITZ, Globalization AND ITS DisCONTENTS (2002) (attributing rigidity of IMF policy prescriptions to ideological zeal).

235 See Duncan Kennedy, Three Globalizations of Law and Legal Thought: 18502000, in Trubek \& Santos, supra note 3, at 19 (discussing periods of legal, institutional, and conceptual change); Mohan Gopalan Gopal, Law-Dependent Public Goods: A Proposed Strategic Framework for a Results-Based Approach to Legal and Judicial Reform (manuscript, on file with author) (discussing international assistance for legal and judicial reform).

236 Sebastian Mallaby, What Wolfowitz Faces, WASH. POST, May 30, 2005, at A21 (describing resistance by World Bank staff to new president, Paul Wolfowitz, and estimating that "[p]robably 90 percent of the bank's staff opposes the Iraq war, and a similar proportion regard President Bush as a dumb cowboy.").

237 For proof that this is the case, see Gopal, supra note 235.

238 See STIGLITZ, supra note 234, at 30 (discussing the power of domestic elites on the global economy). 
one would have to think that there would be substantial slack in political control over the Bank and other IFIs, which would allow law and development practitioners considerable freedom to take criticism seriously and to experiment with different approaches. Why is it then that external critiques seem to have so little impact on law and development approaches?

There may be several factors at play, but certainly one of the reasons outside critiques have limited bite with respect to the law and development institutions is that the people in these bureaucracies who actually do law and development work are understandably drawn to generally applicable models or frameworks they can understand and work with. Critiques often fail to provide such models or frameworks, exhausting themselves with demonstrations that reforms are political, in the sense that they benefit one social group or another, or that context is everything, so that "transplant" problems are insurmountable. But how is a World Bank, USAID or IMF professional supposed to deal with the idea that legal and institutional forms are potentially meaningless until we know everything about the particular milieu in which they are supposed to operate? They, better than anyone, likely understand the poverty of simplistic transplantation approaches. As a USAID official stated when asked to comment on Douglass North's approach:

Although we have long paid lip service to the importance of cultural differences and what we used to refer to as 'social soundness analysis,' we have more often assumed that introducing change based on our own experience will result in a similar outcome in a developing-country environment, where different institutions prevail. And we are very often disappointed with the results. ${ }^{239}$

Yet even if the bureaucrat knows that a simple transplant approach is likely to fail, taking the idea too seriously could be paralyzing, and for people at the working level of a bureaucracy paralysis is not an option.

This dynamic can be illuminated by looking at the way law and development orthodoxies tend to handle ideas that are too

239 Jonathan Conly, Comments on Douglass North's "Understanding the Process of Economic Change" (Forum Series on the Role of Institutions in Promoting Economic Growth, Mercatus Center of George Mason University) 2 (June 24, 2003). 
important to ignore, but that also represent fundamental challenges. Here the work of Friedrich Hayek provides a wonderful example, as his normative aspirations for administrative law infused the Washington Consensus rule of law orthodoxy, ${ }^{240}$ yet his basic theoretical approach, if taken seriously, would be difficult for traditional law and development orthodoxies to digest. To review, Hayek offered a normative vision of the rule of law that he suggested would maximize the predictability of the legal system to private actors, thus facilitating market ordering. ${ }^{241}$ Hayek, like his followers in the neoliberal rule of law tradition, then claims that observation of this rule of law is "a necessary, but not yet a sufficient, condition for the satisfactory working of a free economy." 242 Just as Weber felt that formal rationality would tend to frustrate democratic forces and those who wished to use law to further their substantive commitments, ${ }^{243}$ so Hayek's rule of law would

preclude[s] all those measures which would be necessary to insure that individuals will be rewarded according to another's conception of merit or desert rather than according to the value that their services have for their fellows-or, what amounts to the same thing, it precludes the pursuit of distributive, as opposed to commutative, justice. ${ }^{244}$

Even though Hayek's vision may seem fanciful when one considers the discretion that administrative law allows to government actors even in advanced market economies such as the

240 See supra note 106 and accompanying text.

241 See HAYEK, supra note 106, at 72 ("[G]overnment in all its actions is bound by rules fixed and announced beforehand-rules which make it possible to foresee with fair certainty how the authority will use its coercive powers in given circumstances and to plan one's individual affairs on the basis of this knowledge."). Hayek went on to say that "discretion left to the executive organs wielding coercive power should be reduced as much as possible," so that "[w]ithin the known rules of the game the individual is free to pursue his personal ends and desires, certain that the powers of government will not be used deliberately to frustrate his efforts." Id. at 72-73. See also FRIEDRICH A. HAYEK, THE CONSTTTUTION OF LIBERTY 222 (1960) ("[A]ll coercive action of government must be unambiguously determined by a permanent legal framework which enables the individual to plan with a degree of confidence and which reduces human uncertainty as much as possible.").

242 HAYEK, THE CONSTITUTION OF LIBERTY supra note 241, at 222.

243 See Trubek, supra note 16, at 739.

244 HAYEK, THE CONSTITUTION OF LIBERTY supra note 241, at 232. 
United States, Britain,245 or Germany, 246 let alone in the developmental states of high-growth Northeast Asia,247 it is easy to see why it is so attractive to law and development practitioners, and not only those of the neoliberal bent. ${ }^{248}$ But if one takes Hayek a bit more seriously, particularly his theory of knowledge, his ideas should become problematic even to a law and development project that shares his deregulatory, free-market agenda. The problem with the philosophical, as opposed to the normative, Hayek is that he expressed severe doubts about the ability of any person, or small group, to understand social processes well enough to engage in effective planning. 249 Market outcomes are much less prone to this epistemological problem because they are "spontaneous orders," reflecting the aggregation of individual decisions taken with personal knowledge and out of self-interest, and the common law is exulted over the civil law (and modern statutes) precisely because it develops through a similarly informal, disaggregated process. Such skepticism concerning our ability to grasp the workings of society well enough to engage in planning hardly fits with any of the law and development orthodoxies surveyed here, however, as they all assume that putting the correct legal framework in place will bring about the social changes they desire. And it is no escape from this dilemma to propose just putting in place the minimal legal framework of the "night watchman state" and then letting market forces operate, because we are always dealing with real societies, with real histories, and with existing distributions of wealth and power, which would have to be

245 See DAVID Vogel, NATIONAL Styles of REgUlation: ENVIRONMENTAL POLICY IN GREAT BRITAIN AND THE UNITED STATES 24 (1986).

246 See Edward Rubin, Discretion and Its Discontents, 72 CHI.-KENT L. REV. 1299 (1997) (arguing that German administrative officials in fact wield a great deal of discretionary power).

247 See Ohnesorge, supra note 172.

248 Of course discretion can also be characterized as "flexibility," which was praised by an earlier study of Northeast Asian development. See WORLD BANK, supra note 18, at 167-74; LEROY P. JONES \& IL SAKONG, GOVERNMENT, BUSINESS, AND ENTREPRENEURSHIP IN ECONOMIC DEVELOPMENT: THE KOREAN CASE 132-40 (1980). That flexibility was available because legal systems limited the extent to which administrative law causes of action could be used to intervene to check government decisions at the request of private parties, and, arguably, because relevant government organs enjoyed a relatively high degree of autonomy from interest groups.

249 See Ryszard Legutko, Was Hayek an Instrumentalist?, CRITICAL REV., Winter 1997, at 145, 146-49. 
understood in order to predict the outcomes that the market would produce. Although Hayek might not have called this "planning," it shares the same fundamental difficulty.

One can see the same dynamic with respect to even the work of Douglass North, which provided such a central theoretical justification for the move by the IFIs toward a legal reform agenda of broad, systemic change, during the 1990s. One can take a very different message from reading North himself, however, a message that in some ways echoes Hayek's. North's definition of an institution now includes pretty much everything that anyone thinks might affect behavior, including cultural norms and ideology, 250 and the fact that developing countries do not present a tabula rasa means that North's return to this essentially sociological or anthropological approach ${ }^{251}$ makes him a more problematic theorist of law and development than he was thought to be. For example, in recent years free-market activists at George Mason University's Mercatus Center and at the University of Maryland's IRIS Center have hosted a series of events "to help USAID make its donor assistance more effective and sustainable by incorporating insights from the New Institutional Economics into USAID's programming and delivery of development assistance."252 But a

250 See Douglass C. North, Institutions, J. ECON. PERSPECTIVES, Winter 1991, at 97, 97 "Institutions are the humanly devised constraints that structure political, economic and social interaction. They consist of both informal constraints (sanctions, taboos, customs, traditions, and codes of conduct), and formal rules (constitutions, laws, property rights).").

251 Early in his career North was interested in the work of sociologist Robert Merton, an important figure in the development of modernization theory. See Douglass C. North, Autobiography, http://nobelprize.org/economics/laureates/ 1993/north-autobio.html (last visited Apr. 8, 2007). Although North seldom cites sociologists, his ideas about social institutions and capitalism are not so far from Weber's. North writes as if he has taken on the mantle of Talcott Parsons, searching for a universal paradigm of human action that will unify the social sciences:

It is clear that we had to have an explanation for why people make the choices they do; why ideologies such as communism or Muslim fundamentalism can shape the choices people make and direct the way economies evolve through long periods of time.... I believe that an understanding of how people make choices; under what conditions the rationality postulate is a useful tool; and how individuals make choices under conditions of uncertainty and ambiguity are fundamental questions that we must address in order to make further progress in the social sciences.

Id.

252 Conly, supra note 239 , at introduction. 
USAID employee asked to comment on North's recent work clearly could not find much of programmatic value in it, politely "join[ing] the author of this stimulating paper, who says at its conclusion that he hopes it will inspire scholarly efforts to carry forward a research agenda essential to improving the performance of economies over time." 253 It was clear that the USAID commentator already understood the problem of local context, asking rhetorically "[h]ow often have we tried to assist developing country reformers to introduce new laws to boost free-market competition or to increase transparency or to level a commercial or political playing field only to be stymied by completely ineffective implementation of the news laws? The prevailing institutionsmost often informal constraints - beat us most of the time." It seems obvious that he understood the overwhelming importance of local social context, so that what he seemed to take away from his encounter with NIE and North was new lingo to describe what he already understood.

The dynamic can also be seen in the treatment of the research by Stewart Macaulay, Ian MacNeil, and others who have long chronicled the presence in the most developed market economies of legal informality, relational contracting, and other realities that are not captured well in simple models of how law and economy interact. ${ }^{254}$ They have demonstrated, over several decades of work, that a great deal of American commerce takes place with only tenuous connection to the traditional contract law paradigm of arms-length bargains, resulting in clear contractual rights, which can then be simply enforced by courts. While these writings are cited in the law and development literature, like recent writings on institutions and social norms, each of these literatures, if pushed to its logical conclusion, will present serious challenges to the development practitioner charged with instituting legal system reform in societies and business cultures about which he or she will likely know very little.

In the marketplace of law and development ideas, then, there seems to be a very real need for clear prescriptions that affirm the

253 Id. at 3.

254 See, e.g., Macaulay, supra note 202, at 55 ("[B]usinessmen often fail to plan exchange relationships completely, and seldom use legal sanctions to adjust these relationships or to settle disputes."); Ian R. Macneil, Relational Contract: What We Do and Do Not Know, 1985 WIS. L. REV. 483 (analyzing discrete contracting in the broader scheme of human exchange behavior). 
importance of legal system performance to economic development, yet do so in language that is technocratic rather than overtly political, while also conforming to the positive view of law held by donor countries. Thus, even if one accepts the accuracy of the critique in Section 3, above, there are structural reasons why the law and development industry will remain impervious to criticism by counter-example if the counter-examples cannot be packaged into some sort of coherent alternative program. What follows is a preliminary effort to show how such a package might be constructed, based upon fairly well recognized aspects of law in modern Northeast Asia. Section 4.2. reviews areas of law and legal system performance that are generally viewed as important for economic development, yet which in Northeast Asia have often failed to function in ways demanded by the law and development literature. Section 4.3. then builds upon these "failures" to offer an alternative approach to law and development work, an approach that better fits the Northeast Asian experience, while also representing a realistic alternative to current law and development approaches.

\subsection{Northeast Asia's Legal "Failures" as the Basis for an Alternative Approach to Legal Development Assistance}

If we look at all the ways in which Northeast Asia's legal systems fail to meet the claims of the law and development orthodoxies, we are confronted with quite a catalogue of failures. Legal systems in high growth Northeast Asia failed in many ways to move beyond formalist thinking, failed to put judiciaries and problem-solving lawyers at the center of the governance process, failed to serve as convenient fora for private litigation to enforce property and contract rights, failed to protect minority shareholder rights, failed to take intellectual property rights, competition law, or insolvency law very seriously, and failed to legalize stateprivate sector relations through constitutional and administrative law. This creates a serious problem if, like each of the law and development orthodoxies discussed here, one wants to claim that any particular legal system attribute is really necessary for development. But if one seeks instead to develop a theory of law and development inductively, by looking at how law actually functioned in Northeast Asia during high-speed economic growth, these "failures" disappear, replaced by ranges of performance amenable to functional analysis in ways that the "failures" view is 
not. The Northeast Asian experience counsels, however, that the functions of various areas of law cannot be simply assumed, but must themselves be opened up to redefinition based upon empirical study.

\subsubsection{Northeast Asian Legal Instrumentalism and the Compartmentalization of Law}

With respect to legal instrumentalism, Northeast Asia's experience establishes a couple of facts. First, instrumentalism beyond the American "liberal legality" norm associated with the modernization orthodoxy, whether of the relatively benign Japanese variety or the virulent Korean style, is perfectly compatible with rapid economic growth. While this may cause problems for those committed to traditional legal values, another strand of the modernization tradition was always a bit skeptical of lawyers and legality hamstringing the state as it pursued its modernizing mission.255 But even if one defines development more broadly, as under the modernization and comprehensive development approaches, the Japanese experience shows that a thoroughly modern society can allow a degree of legal instrumentalism beyond even the modernization model, accomplished through constraining judges to decide individual cases according to the norms of the bureaucracies within which they work. ${ }^{256}$ Whether the ultimate principals were Japan's politicians or the judges at the top of the judicial bureaucracy, the result for Japan has been that the judiciary has not become an active participant in the overall governance system to anything like the degree federal courts are in the United States. But it has become very clear now in the United States that the idea of a nonpolitical consensus on the independence of our judiciaries, federal as well as state, was one of those attractive fictions from a less polarized era. ${ }^{257}$ While this might have disappointed the law and development practitioners of the 1960s, as it has disappointed many critics of Japanese public law, it would probably not have

255 GILMAN, supra note 38, at 228-34 (discussing Samuel Huntington).

256 See Upham, supra note 149, at 454 (advocating that a judiciary, constrained by bureaucracy, can be beneficial for certain systems).

257 See Julian Borger, Former Top Judge Says U.S. Risks Edging Near to Dictatorship, GUARDIAN, Mar. 13, 2006, available at http://www.guardian.co.uk/ frontpage/story $/ 0,1729656,00 . \mathrm{html}$ (reporting on speech by retired Justice Sandra Day O'Connor). 
disappointed the Americans who drafted the Japanese constitution during the occupation era, whose New Deal sensibilities about judicial versus executive and legislative power were more like those that have prevailed in Japan..$^{258}$

Finally, if we remain uncomfortable with legal instrumentalism in the Third World, or at home, it is worth asking whether legal reform programs can be presented in a truly non-instrumental way. This is an attractive idea, which recurs in places like the "credible commitments" literature, as it adopts a pre-Legal Realist faith in the ability of constitutional text and institutional arrangements to insulate property from politics. But from the jaded perspective of 2006 it is hard to imagine how this ever could have been persuasive to Third World elites: "We're here to help you make your legal system into an effective tool to reorder your society, but do not try this yourself because law is not a tool."

\subsubsection{Legal Education, Legal Professions, and the Social Role of the Formal Legal System}

Several other aspects of Northeast Asia's legal systems that contradict claims of the law and development orthodoxies can be understood as relating to the general role of law and the formal legal systems during the high-growth periods. As we have seen, legal education remained far too doctrinal and formal to satisfy the modernizers of the 1960s, while local bars were kept tiny because governments set very low quotas of those allowed to pass the licensing exams in any given year. Thus while the people who became fully licensed lawyers had received traditional civil law training, and had been forced to memorize enormous amounts of doctrine in order to pass the exams, they were both extremely capable,259 and extremely hard working. Governments also kept their judiciaries very small by international standards, but being a judge was an attractive enough career option to guarantee that very capable people staffed the bench. While the judges who staffed these judiciaries were on the whole highly competent, however, they were subjected to supervision and control by

258 See JOHN OWEN Haley, AUTHORITY Without POWER: LAW AND THE JAPANESE PARADOX 148-49 (1994) (discussing Occupation-era reforms shifting authority from the Diet to the bureaucracy).

259 This is true even if one believes that there are different ways to define intelligence, and that ability to memorize and regurgitate material is only one of them. 
superiors who held fundamentally conservative, pro-development political views, and who believed in a restrained role for the judiciary in the governance system.

Undergraduate law departments were numerous, however, turning out thousands of law-trained graduates each year who had no hope of becoming fully licensed lawyers, but who instead went into government service, worked in corporate legal departments, or worked in one of the law-related professions such as notaries. Small bars helped guarantee that legal services necessary to access the formal system would be expensive, despite the fact that many people received training in law. Furthermore, access to the formal system was discouraged by professional rules concerning legal fee arrangements, procedural rules concerning such things as the posting of court costs, and the fact that litigation consisted not of "trials" in the United States sense, but of a series of hearings that could drag on for years even in simple cases. While recent developments suggest that many in Northeast Asia are no longer satisfied with this long-standing settlement, the question is whether it might have played any positive role in the development process.

One possibility has to do with the allocation of scarce resources. A possible virtue of this arrangement is that it helped guarantee that law would be "potent" in that it permeated the internal workings of both government bureaucracies and business organizations, a desire that will probably accompany any law and development effort. It is arguable that this "potency" was achieved at a relative bargain price, however. Providing undergraduate legal education through lecturing to large classes was comparatively cheap, with more labor-intensive training reserved for those very few who had passed the bar exam and would staff the formal system, either as judges, lawyers or prosecutors.

The system's approach to the judiciary might also be seen as a rational approach to the "potency" problem in conditions of limited resources. Because the systems generally discouraged both private and public law litigation, it was possible to spend relatively little on the judiciaries, yet still have them produce coherent, technically competent adjudication in those comparatively few cases that they decided. ${ }^{260}$ Furthermore, while many would object

260 This appears to be the consensus view of the Japanese judiciary, for example, despite other differences among commentators. See Upham, supra note 
to the control that could be exercised within these systems with respect to the decisions of individual judges, one effect of that control was to maintain and enforce a relatively limited role for law and the courts in the broader political economy. Leaving aside the dangers of judiciaries subservient to political control, if we engage in a comparative institutional analysis, considering the courts alongside the other organs of government, it certainly seems plausible that from a purely economic point of view the judiciary should be limited in its ability to define its own role in governance. Of course the body doing the controlling could let the individual decision stand, then act politically to limit the undesired extension of law, but there are reasons that might be difficult. If the decision is on constitutional grounds even an authoritarian political system may feel constrained in its ability to change the constitution, or if, as Haley argues was the case in Japan, the controlling body is the head of the judicial bureaucracy rather than a political branch, then that body may have no legal statutory authority, and may prefer to keep the political branches away from its domain. The style of legality it produced, however, was more constrained than would be produced by the more "modern" ideal type of large and competitive bars, larger and less disciplined judiciaries, and greater incentives to litigate.

\subsubsection{Contract and Property Rights Enforcement}

It would be extreme to suggest that a modern market economy could function without law to define property and contract rights, and without courts available to adjudicate disputes that will inevitably arise as market actors transact based upon these rights. Unfortunately, however, the law and development literature too often speaks of judicial dispute settlement in binary terms: it is either available to enforce contracts and property rights, or it is weak, corrupt, ineffective, or something equally repugnant. A better way to look at the issue would be to start with the view that any functioning legal system will again present a trade-off, or continuum, with respect to its attractiveness to litigants. A legal system that makes it too easy to resort to litigation will destroy a certain number of beneficial business relationships that are under stress but that might be salvaged by the parties were litigation a less attractive alternative. In other words, judicial dispute

149 at 435 (discussing the ease by which judges are corrupted). 
settlement may "crowd out" private dispute settlement at a cost to the economy. A legal system that makes private litigation entirely implausible, on the other hand, would leave enforcement of contracts to the parties, and property rights to the criminal law.

Northeast Asia's legal systems have been consistently described as comparatively unfriendly to litigation, a characteristic that was certainly responsible, at least in part, for relatively low litigation rates and a perceived tendency to rely on non-judicial settlement of business disputes. While it may be that this approach hindered economic development, or was simply irrelevant, it is at least possible that they settled closer to the ideal point on the continuum than the United States, for example. In any case, this experience demonstrates that one ought to ask if a legal system creates roughly appropriate incentives to private litigation, yet this question seems absent from much law and development writing.

\subsubsection{Intellectual Property Law}

Protection of intellectual property rights presents all societies with tradeoffs. An important tradeoff is that between encouraging investment in research and development, which is normally understood to be furthered by rigorous IPR protection, and encouraging the diffusion of technology and the resulting competition, which argues for more limited IPR protection. That this tension between incentive-producing and anti-competitive aspects of intellectual property protection is not easily resolved is shown by the fact that the United States Supreme Court recently decided a key issue concerning the relationship between patent and antitrust law.261

For developing countries, which by definition have few or no industries operating at the technological frontier and few industries with substantial R\&D capabilities, an important tradeoff concerns the cost of acquiring technology from abroad. ${ }^{262}$ Lax

261 See III. Tool Works Inc. v. Indep. Ink, Inc., 547 U.S. 28 (2006) (resolving in the affirmative the issue of whether plaintiffs alleging an anti-competitive tying arrangement by a patent holder must prove defendant's market power); Tony Mauro, Supreme Court Considers Limiting Antitrust Suits Against Patent Holders, LEGAL TIMES, June 21, 2005, available at http://www.law.com/jsp/article.jsp?id= 1119270947813.

262 For a discussion of these dynamics in the case of China, see Alan Cox \& Kristina Sepetys, Intellectual Property Rights Protection in China: Litigation, Economic Damages, and Case Strategies, in ECONOMIC APPROACHES TO INTELLECTUAL PROPERTY 293 (Gregory K. Leonard \& Lauren J. Stiroh eds., 2005). 
protection for foreign-owned IPR, which can be achieved by the formal IPR rules, the procedural rules, the technology import screening regime, or their enforcement, will make it cheaper for local entrepreneurs to localize many technologies useful to a developing economy. Whether or not this will benefit the developing economy as a whole will depend upon whether there are good reasons to favor local ownership over foreign investment, whether there are local businesses capable of using the technology, and if so, whether they use it well.

An admittedly favorable interpretation of the Northeast Asian experience is that lax protection of foreign-owned IPR can be successful, though success may have to be defined in part economically and in part nationalistically. Investment in domestic educational systems, and the ability to lure back foreign-educated nationals, provided the necessary technological base for appropriating foreign technology, while competition, sometimes in export markets, sometimes in domestic markets, pressured the domestic technology importers to use the technology productively. Pressure to export seems to be an important part of the equation, however, as does a debatable judgment in favor of national over foreign ownership. In addition, the costs of weak IPR enforcement, which can include exclusion of products from export markets ${ }^{263}$ as well as reduced incentives to local R\&D, would have to be taken into account.

Despite the complexity inherent in this view of IPR protection by developing countries, it seems preferable to mainstream law and development approaches. First, it is a view that at least attempts to make sense of the coexistence of weak IPR and economic and technological success in Northeast Asia. Second, it seeks to get beyond the binary "strong" versus "weak" view of IPR protection, a view that appears too often in the literature despite its obvious weaknesses. Finally, it is a view that leaves some room for national government agency. For those who mistrust government this may be a bad thing, and maybe individuals in Northeast Asia would be better off now if their national governments had vigorously and evenly protected local and foreign IPR. But that's not what those governments did, nor did they seek to insulate the legal regime so that IPR could be enforced by courts or other

263 For example, United States intellectual property rights holders may petition to block the importation of goods manufactured abroad in violation of their intellectual property rights. See 19 U.S.C. $\$ 1337$ (2000). 
institutions divorced from politics.

\subsubsection{Additional Examples}

The ability of minority shareholders in publicly traded corporations to use the legal system to sue managers or majority shareholders again presents us with a continuum and potential trade-offs. At one extreme, litigation would be an entirely ineffective threat, either because of limited legal theories or because of unfriendly procedural rules, while at the other extreme management and majority owners would be inhibited from desirable risk-taking for fear of being second-guessed via shareholder litigation. The Northeast Asian approach was clearly far toward the non-threat end of this continuum, which arguably makes a good deal of sense for a developing country. Shareholders in publicly traded companies always have the "Wall Street option" of selling their shares, and one could argue that the last thing corporate managers in developing countries need is to be monitored by courts entertaining shareholder litigation, so long as they are monitored via the criminal law and tax law, by their creditors, or in some other non-trivial way.

Insolvency law is another example of a body of law that would have to be deemed a failure in Northeast Asia according to the law and development orthodoxies. An "effective" insolvency law regime became part of the neoliberal orthodoxy of the 1990s, but Northeast Asia's insolvency regimes also would have been failures in the modernization mindset because they represented bodies of "modern" law that functioned only minimally, or not in accordance with their proper purpose.264 With respect to insolvency law, a trade-off would involve balancing the benefits of "creative destruction" and the protection of creditors against potential costs to industrial development and social stability. It is not, as the law and development literature typically assumes, simply a matter of effectively enforcing creditors' rights.

Competition law and policy presents another potential continuum, and the Northeast Asian approach has been neither "effective," in the sense of rigorously attacking anti-competitive practices, nor has it been left free to operate on its own, separate from larger concerns of political economy. Rigorous enforcement

264 See Ron W. Harmer, Comparison of Trends in National Law: The Pacific Rim, 23 BROOK. J. INT'L L. 139 (1997) (discussing Japan's insolvency regime). 
potentially favors competition, and thus consumers, but overly rigorous enforcement could limit the ability of domestic companies to achieve the scale necessary to compete internationally. As noted earlier with respect to the comprehensive development rule of law, labor law regimes in Northeast Asia have also long been criticized by local and foreign observers. While this is not a call for developing countries to violently suppress labor, as the Korean government was known to do, an empirical approach to law and development based on Northeast Asia's practices cannot ignore the realities of the region's labor law. Moreover, these regimes were in place when the Northeast was achieving not only growth, but "growth with equity," to use the World Bank's phrasing. Finally, the limited role of administrative law during rapid development in Northeast Asia prompts one to weigh the costs of such an approach against the costs of a more expansive role. If the key task of administrative law is to ensure a basically law-governed bureaucracy, then Northeast Asia's bias in favor of internal bureaucratic controls, including legal education for many bureaucrats and comparatively high status, may be a reasonable alternative to facilitating external control via judicial review. But while keeping the courts in such a limited posture vis-à-vis the bureaucracy may help facilitate the flexibility for which Northeast Asia's economic bureaucracies have been praised, there are obvious costs. Judicial review can be a useful force for bureaucratic rationality if it forces the bureaucracy to publicly explain and justify its actions, and of course internal controls on a bureaucracy may suffer from being enforced by the bureaucracy itself.

Reducing the foregoing analysis to a "Northeast Asian Law and Development Chart" would result in something like the following:

TABLE 1: NORTHEAST ASIA"S LEGAL “FAILURES" IN DEVELOPMENT PERSPECTIVE

\begin{tabular}{|l|c|c|c|}
\hline & $\begin{array}{c}\text { Low Functioning } \\
\text { (Possible } \\
\text { Advantages): }\end{array}$ & $\begin{array}{c}\text { Northeast Asia's } \\
\text { Performance: }\end{array}$ & $\begin{array}{c}\text { High Functioning } \\
\text { (Possible } \\
\text { Advantages): }\end{array}$ \\
\hline
\end{tabular}




\begin{tabular}{|c|c|c|c|}
\hline $\begin{array}{l}\text { Public Resources } \\
\text { Devoted to Courts } \\
\text { and Facilitating } \\
\text { Litigation }\end{array}$ & $\begin{array}{l}\text { Encourages } \\
\text { settlement; Frees } \\
\text { resources for other } \\
\text { uses }\end{array}$ & $\begin{array}{l}\text { Low (few judges, } \\
\text { lawyers } \\
\text { expensive, } \\
\text { procedural rules } \\
\text { not encouraging } \\
\text { to litigation) }\end{array}$ & $\begin{array}{l}\text { Facilitates rights- } \\
\text { based market, } \\
\text { business planning }\end{array}$ \\
\hline $\begin{array}{l}\text { Role of Legal } \\
\text { Profession in } \\
\text { Society and } \\
\text { Governance }\end{array}$ & & $\begin{array}{l}\text { Low (but many } \\
\text { legally trained in } \\
\text { business and } \\
\text { government) }\end{array}$ & \\
\hline $\begin{array}{l}\text { Contract and } \\
\text { Property Formality }\end{array}$ & $\begin{array}{l}\text { Lower } \\
\text { documentation } \\
\text { costs; may } \\
\text { discourage } \\
\text { litigation, } \\
\text { encourage } \\
\text { negotiated } \\
\text { settlement }\end{array}$ & $\begin{array}{l}\text { Low (short, } \\
\text { general } \\
\text { documents; } \\
\text { relational } \\
\text { contracting) }\end{array}$ & $\begin{array}{l}\text { May facilitate } \\
\text { planning; protect } \\
\text { rights of weaker } \\
\text { party }\end{array}$ \\
\hline $\begin{array}{l}\text { Intellectual } \\
\text { Property Rights }\end{array}$ & $\begin{array}{l}\text { Facilitates } \\
\text { acquisition and } \\
\text { diffusion, } \\
\text { especially of } \\
\text { foreign IP }\end{array}$ & Low & $\begin{array}{l}\text { Encourages } \\
\text { investment in } \\
R \& D \text {, innovation; } \\
\text { avoids trade } \\
\text { friction }\end{array}$ \\
\hline $\begin{array}{l}\text { Shareholder } \\
\text { Litigation }\end{array}$ & $\begin{array}{l}\text { Allows } \\
\text { management more } \\
\text { discretion to take } \\
\text { risks without fear } \\
\text { of litigation }\end{array}$ & Low & $\begin{array}{l}\text { Helps keep } \\
\text { management, } \\
\text { controlling } \\
\text { shareholders } \\
\text { focused on } \\
\text { interests of all } \\
\text { shareholders; } \\
\text { facilitates external } \\
\text { finance }\end{array}$ \\
\hline Bankruptcy & $\begin{array}{l}\text { Preserves value of } \\
\text { businesses; } \\
\text { encourages } \\
\text { negotiated } \\
\text { solutions }\end{array}$ & Low & $\begin{array}{l}\text { Facilitates } \\
\text { "creative } \\
\text { destruction," } \\
\text { reallocation of } \\
\text { resources; } \\
\text { encourages } \\
\text { extension of credit }\end{array}$ \\
\hline
\end{tabular}




\begin{tabular}{|c|c|c|c|}
\hline Antitrust & $\begin{array}{l}\text { Allows } \\
\text { coordination to } \\
\text { avoid "overheated } \\
\text { competition"; } \\
\text { facilitates } \\
\text { economies of } \\
\text { scale"265 }\end{array}$ & $\begin{array}{l}\text { Low (more a } \\
\text { policy of } \\
\text { regulating cartels } \\
\text { than combating } \\
\text { them) }\end{array}$ & $\begin{array}{l}\text { Forces competitive } \\
\text { focus }\end{array}$ \\
\hline $\begin{array}{l}\text { Administrative } \\
\text { Law (scope and } \\
\text { judicial } \\
\text { enforcement) }\end{array}$ & $\begin{array}{l}\text { Frees agencies to } \\
\text { exercise expertise, } \\
\text { without fear of } \\
\text { judicial review }\end{array}$ & $\begin{array}{l}\text { Low } \\
\text { (comparatively } \\
\text { narrow coverage; } \\
\text { limited judicial } \\
\text { role) }\end{array}$ & $\begin{array}{l}\text { Enforces limits on } \\
\text { agency } \\
\text { jurisdiction; } \\
\text { combats agency } \\
\text { capture, } \\
\text { arbitrariness; } \\
\text { protects citizens } \\
\text { from bureaucracy }\end{array}$ \\
\hline
\end{tabular}

\subsection{Putting Substance over Form in Legal Technical Assistance}

Now that these historical failings of Northeast Asian legality have been recast as trade-offs on a series of policy continua, is it possible to forge from it something that can contribute positively to the law and development literature, rather than serving simply as material for critique? The answer is yes, but to do so, it will be helpful to see mainstream law and development literature as overly influenced by Max Weber's ideal type of formal legal rationality, which he argued was bound up in important ways with the development of modern capitalism. ${ }^{266}$ For Weber, the "formal" in formal legal rationality meant that legal reasoning referred only to the internal logic of the legal system itself, not to "substantive" value systems or ideologies.267 In his view, this resulted in a high degree of autonomy for law, and maximized the predictability of legal outcomes to private actors. ${ }^{268}$ Substantive

265 Mark Tilton, Restrained Trade: Cartels in JaPan's Basic Materials INDUSTRIES 29 (1996) (citing ALICE H. AMSDEN, ASIA'S NEXT GIANT: SOUTH KOREA AND LATE INDUSTRIALIZATION 8 (1989)).

266 See Trubek, supra note 16, at 722 (delineating Weber's concept of legal formalism as tied into sociological theory).

267 See id. at 733. (discussing the importance of formal legal rationales to create general rules).

268 See id. at 737-38 (holding that reason actors obey the law is because they believe the law is rational). 
rationality, on the other hand, prevailed when non-legal value systems, such as Confucianism, informed the reasoning of legal decision makers. ${ }^{269}$ Although not exactly reproducing Weber's ideal-types, each of the law and development orthodoxies discussed here betrays its own variant of formalist thinking, which renders it incompatible with the Northeast Asian experience.

The modernization orthodoxy has been criticized for simplistic assumptions about law, 270 although in its understanding of legal formalism as a problem it evidenced much more sophistication about how legal systems work than its successors. More important was the formalism that that approach displayed in its idea that modernized legal institutions, staffed by modernized people, would produce reliably modern outcomes, with "modern" meaning outcomes that essentially conformed to mid-twentieth century American ideals. The formalism inherent in the Washington consensus rule of law orthodoxy shares some of the aspects of its predecessor, in the idea that "getting the rights right" is the key to thriving markets, for example, but also takes a much more formalist approach to law itself, thus calling for something much closer to Weber's formal legal rationality.271 Formal rationality calls for legal systems to operate and evolve with no particular substantive societal goal, guided only by the internal logic of the legal order, as understood by the trained adept. Even if the rule structure were set up in a way that would seem conducive to market-oriented growth, however, given the indeterminacy inherent in any legal order, the internal logic of the legal order cannot be trusted to keep the operation of the system oriented toward growth. And while property rights were obviously important in the market economies of Northeast Asia, given the diminished role for litigation as the "enforcer" of property rights as well as the noted tendency towards informality in contracting behavior and in organizational form, it is clear that the relationship between the written law and the behavior of economic actors was far more complex than the orthodoxy.

The legal origins proto-orthodoxy is prone to similarly formalist tendencies, as it radically overestimates the closeness of

269 Id.; see also MAX Weber, THE RELIGION OF CHINA (Hans H. Gerth trans., 1951) (depicting adjudication of disputes by traditional Chinese magistrates as being driven by substantive, extra-legal concerns).

270 Trubek \& Galanter, supra note 38.

271 For Weber's typology of legal systems, see Trubek, supra note 16. 
the fit between formal rules and structures and real economic behavior, an overestimation on which the plausibility of its formalist methodology depends. Finally, like the modernization approach, the comprehensive development approach assumes that the social outcomes it desires will be obtained if the specific legal rules and institutions it supports will perform the functions assigned to them in the theory.

The existing orthodoxies are prone to these kinds of formalism for two reasons. The first, discussed above, is that organizations that do law and development work are staffed by people who need generally applicable frameworks that they can apply around the world, and frameworks of that sort are prone to formalism. It is not simply the need for generally applicable ideas that is the problem, however, but the fact that the actual substantive results, the societal ends which law and development activities should be serving, become secondary to the task of creating the legal rules and institutions that the various orthodoxies claim produce those outcomes. In the words of one long-time World Bank law reform practitioner: "[t]he conventional approach sees legal and judicial reform as an intrinsic good, based on the belief that once legal concepts and institutions of a particular model are established, positive development outcomes will follow-economic, social and political." 272

What is needed, then, is not a new orthodoxy based on what we think happened in Northeast Asia, but a new approach to law and development. That new approach would reject the existing practice, in which successive models are presented as the solutions to the development problem, an inescapably formalist approach. Rather than presenting yet another model, the new approach would engage with developing countries based upon something like Table 1 in Section 4.2.5., recasting areas of law as continua along which successful legal systems vary, and offering realistic appraisals of the tradeoffs involved. In other words, legal technical assistance would consist of presenting legal reform issues as we actually think about them ourselves, as ridden with tradeoffs, so that where a legal system falls on a particular dimension is important, and not whether property rights are "secure," or some other abstraction. The presentation would include such evidence as we have about how successful economies have approached these

272 Gopal, supra note 235. 
tradeoffs, and it would be through these appraisals that Northeast Asia's experience could make an enormous contribution, rather than as the basis for yet another orthodoxy. And because individual legal fields are very often related, the approach would include such evidence as we have of the ways that choices about one area of law or legal institution might affect others - even if one thought, despite Northeast Asia's experience, that developing countries should aim for a high level of functioning in all the areas of law contained in the chart above, in a world of limited resources that is not a realistic possibility. Thus another important contribution of the approach outlined here is that it could be used to help prioritize among various reform possibilities. For example, countries with relatively clean, competent bureaucracies might decide not to devote as many resources to administrative law reform, while countries with strong science education and a desire to foster domestic industry, such as China today, might choose to postpone heavy investment in intellectual property protection until such protection is demanded by local IP owners.

In a macro sense, the Northeast Asian experience suggests that if the goal is economic development, the legal system as a whole should operate in a mode more similar to Weber's substantive rationality than to his formal rationality, with the "substance" provided by a commitment to industrialization and economic growth. This does not mean copying the specific policy decisions of Northeast Asian economies, because the realm of available policy options is constantly changing, and because that would constitute yet another questionable orthodoxy. It would mean, however, approaching the legal system as a tool that should be operated to achieve rapid economic development, which would tend to shift the focus from rules and institutions to outcomes. Such outcomes might be controversial, in the sense of favoring accumulation over redistribution, management over shareholders, and industrialization over the environment, but they might not. At least these important distributional questions would be out in the open, rather than being clouded by rhetoric.

What changes would be required under this new approach? The most important would be for law and development activities to move up a level of engagement, to focus on providing options based upon experience instead of providing answers. In order to do this, it would be very useful to take a team approach to staffing law and development projects, with teams to include both common law and civilian lawyers, but also lawyers from successful 
developing countries. It would also be crucial for legal assistance providers to abandon the idea that their job includes pursuing some broader agenda, such as maintaining the international financial system or the WTO. There is a tendency to want all good things to go together, to want what is good for any particular developing country to also be good for the rest of the world. It is clear from the Northeast Asian experience that sometimes countries benefit from behaving strategically in their interactions with the world, however, so if we really want to help them we should focus on their particular development concerns, and let someone else worry about maintaining the international economic order. Even if strategic behavior is never actually helpful, however, it seems that economic nationalism has played an important role in Northeast Asia's success. Most developing countries are too insignificant economically for a bit of nationalism to endanger the world economy, and the big countries such as China can largely ignore legal assistance efforts that they think are not in their interests. The world should encourage developing country governments to be concerned, first and foremost, about national development, even at the expense of their trading partners or the international economic order. Finally, legal assistance practitioners would need to be able to separate themselves from their own national experience, to be open to the fact that something might be useful to a developing country even though their own country has moved away from that practice. This would reject simple "best practices" approaches, which assume all countries of the world have essentially the same needs, in which case there might actually be a set of non-controversial, apolitical, scientifically-verifiable "best practices." Best practice for a developing country today might be the Korean corporate governance in the 1970s, for example, rather than Korean corporate law as of 2005, let alone United States corporate law.

Moving up a level of generality and adopting a "substantive rationality" approach would also help ameliorate the "legal transplant" problem that has bedeviled law and development activities from the beginning. Outsiders would be out of the business of advocating particular rules with particular results in mind, so the problem of rules not transplanting with the intended functional results would disappear. And while outsiders would still advocate for basic institutions such as courts, securities regulators, patent offices, or antitrust authorities, it would be recognized that such institutions can play a variety of roles even in 
successful market economies, and certainly during development. The question then becomes whether the various institutions are functioning so as to support or to impede economic growth, not whether they have been effectively "transplanted." New rules and institutions will often not function as anticipated, and while being aware of the transplant problem is useful, the new model's "substantive rationality" calls for continuous monitoring and adjustment, ${ }^{273}$ rather than unrealistic expectations followed by followed by exasperation.

Putting this approach into practice would place serious demands on those involved, because a substantive rationality approach would require accurate and continuous monitoring of affected legal systems, to see whether the goals of particular areas of law were being met, and to facilitate intelligent adjustments if not met. Adjustment would necessarily involve learning by doing, not by rote, or by hectoring. If donor governments or organizations want to place conditions on their law and development assistance, the appropriate conditions should also become "substantive" rather than formal, being based not on whether the new rule or institutions exist on paper, but on whether the recipient government was taking seriously the task of monitoring and adjusting the new legal rules or institutions so as to facilitate economic growth. Because one of the dimensions along which all legal systems fluctuate involves the twin concerns of stability - to facilitate private planning, and flexibility - to allow necessary change, the processes by which adjustments would be made would also be open to evaluation.

Finally, moving up a level would help solve the intractable problem of political interference by allowing the local political process to take responsibility for making the decisions that will affect where the legal system will land on the various continua. Law and development orthodoxies contain within them political choices, and offering an empirically-based menu of options, rather than yet another orthodoxy, puts the choices up front, for all to see. As the example of Korea's post-Financial Crisis reforms show, the fact that international institutions get invited in by a particular government does not make reforms non-political; it just means that

273 See Gopal, supra note 235, at 5 (calling for "programmatic flexibility to 'tweak' interventions until they are able to produce the desired outcomes/results" which "will call for continuing adjustments at the policy and operational level by implementing agencies"). 
the foreign organization is acting in league with the particular faction holding power, but perhaps completely against the wishes of the domestic opposition. When South Korea needed to be bailed out by the IMF and World Bank in 1998, President Kim Dae-Jung, a life-long opponent of authoritarian politics and the chaeboldominated economy, was trying to transition to an entirely new political economy, from bank to financial market financing, to anticartel policies rather than cartel supervision, to corporate governance reforms to limit the powers of chaebol families, and to bankruptcy reform to try to make the formal legal system more relevant. While this was all obviously economic, essentially trying to move Korea closer to U.S.-style economic governance, it was also highly political because it constituted a direct attack on the powerbase of the political opposition, the conservatives and their chaebol supporters. For the IFIs to take sides in this was not only political interference in the most formal sense, but it also makes one wonder about the "participatory" or "ownership" claims of the legal assistance providers. Lining up a coalition of local politicians and civil society groups to enact, over the objections of a sizeable political opposition, a particular set of rules which have obvious distributional consequences, makes the legal assistance providers direct players in local politics. Given the fact that law and development orthodoxies cannot seem to make sense of the Northeast Asian development miracle, there is reason to doubt that just getting the right set of rules in place is ever going to be the answer. Moreover, unless local politics can be permanently suppressed, a method that crams down a set of rules or institutions over the objection of a significant opposition cannot achieve "ownership," but is likely to be either subverted in implementation, or reversed when political fortunes change.

\section{CONCLUSION}

Until perhaps very recently, Northeast Asia's legal systems have conformed to none of the orthodoxies of law and development, yet these were the systems in place as their societies underwent the most successful episodes of economic development in modern history. This is obviously a problem with the ways in which the theories have been produced, which have not included careful study of Northeast Asia. Yet what is needed is not a new orthodoxy in which whatever we think Northeast Asia did would be reduced to a template, to be imposed on today's developing 
countries. Rather, what is needed is a new approach that learns from Northeast Asia, but that also recognizes the limits of the ways in which past law and development orthodoxies were used.

This Article sets out the foundations of a framework to inform the work of law and development providers. But can providers such as the IFIs, USAID, or JICA adopt the approach suggested here, to help developing countries orient their legal systems toward a substantively rational emphasis as outlined above? One precondition would seem to be that the IFIs adopt a perspective that allows them to advance the interests of particular developing countries even if those interests conflict with interests of developed countries, or of the international community. The points at which Northeast Asia's legal systems settled on the performance continua discussed above have been problematic from the perspective of foreigners wanting to participate in their economies, and the globalization of investment and finance only makes this worse. Local disregard for minority shareholder rights, for example, was not a matter of concern for foreign investors in high-growth Northeast Asia because their access to portfolio investment was substantially limited. Likewise, foreign lenders to the region were not that concerned about local insolvency regimes until they started lending to local private borrowers, not governments, and until governments stopped supervising the process and providing explicit or implicit guarantees.

At present, the dominant mindset seems to be that there can be no conflict between local and foreign interests because foreign interests represent the market, so their wishes become the benchmark for proper market economy regulation. With something as technical as economic law reform, however, it seems likely that there will be many specifics that can be handled so as to promote local investment and industrialization that will not matter much to foreign actors. The IFIs must at least be able to focus on what is best for individual developing countries when looking at these factors. If they and other law and development practitioners can get that far, then they should try to encourage developing countries to orient their legal systems towards assisting economic development in a substantively rational way. This will raise a host of practical problems, but at least these problems will be visible.

While current law and development scholarship seems to support reliance on formal models, such an approach only obscures necessary policy choices in favor of a focus on formal rules and institutions, and the success rate of such approaches has 
not been high. The problem begins when models are built that purport to explain law's role in economic development, but that ignore the functioning of law in the Northeast Asian miracle. As was recently said of a theory purporting to explain the rise of "total war," "any theory of total war where the First World War is a distraction sounds like a theory of something other than total war." 274 Likewise, a theory of law and development can come to terms with Northeast Asia. The difficulties continue when the implementation of law reform projects is overtaken by a formalist logic which assumes that if certain reforms are enacted the desired results will follow. Projects thereby become self-referential, judging themselves based on how they have changed the legal system, rather than on how they have affected social reality. The goal of this Article is to offer a way forward based upon a new method for creating law and development theory, and a new approach for law and development practice.

274 Adam Gopnik, Slaughterhouse: The Idealistic Origins of Total War, NEW YORKER, Feb. 12, 2007, at 82-83 (reviewing DAVID A. BELL, THE FIRST TOTAL WAR, NAPOLEON'S EUROPE AND THE BIRTH OF WARFARE AS WE KNOW IT (2007)). 